ERC Working Papers in Economics 18/11

October / 2018

\title{
Public versus Private Sector Wage Gap in Egypt: Evidence from Quantile Regression on Panel Data*
}

\author{
Aysit Tansel \\ Department of Economics, Middle East Technical University, Ankara, Turkey \\ E-mail: atansel@metu.edu.tr
}

Halil Ibrahim Keskin

Department of Econometrics, Cukurova University, Adana, Turkey

E-mail: halil.keskin27@gmail.com

Zeynel Abidin Özdemir

Department of Economics, Gazi University, Ankara, Turkey

E-mail: zabidin@gazi.edu.tr 


\title{
Public versus Private Sector Wage Gap in Egypt: Evidence from Quantile Regression on Panel Data*
}

\author{
Aysit Tansel \\ Department of Economics \\ Middle East Technical University, 06800 Ankara, Turkey \\ E-mail: atansel@metu.edu.tr \\ Telephone: + (90) 312102073 \\ Institute of Labor Economics (IZA) Bonn, Germany and \\ Economic Research Forum (ERF) Cairo, Egypt \\ Halil Ibrahim Keskin \\ Department of Econometrics \\ Cukurova University, Saricam, Adana, Turkey \\ E-mail: halil.keskin27@gmail.com \\ Phone: +(90) 32233872 54- 156 \\ Zeynel Abidin Ozdemir \\ Department of Economics \\ Gazi University, Besevler, 06500 Ankara, Turkey \\ E-mail: zabidin@gazi.edu.tr \\ Phone: + (90) 3122161115 \\ Economic Research Form (ERF), Cairo, Egypt
}

December 3, 2017

This version: October 15, 2018

\begin{abstract}
This paper considers the public and private sector wage earners in Egypt and examines their wage distribution during 1998-2012 using Egyptian Labor Market Panel Survey. We estimate the publicprivate sector wage gap with Mincer wage equations both at the mean and at different quantiles of the wage distribution. In this process we take into account observable and unobservable characteristics of the individuals using the panel feature of the data with a fixed effects model. We address sector of employment selection issue for both males and females. We find that there is very little evidence of sample selection in our data. Therefore, we present both the selection corrected results and the results with no selection correction. We find a persistent public sector wage penalty for males and public sector wage premium for females in the face of extensive sensitivity checks. They are larger when unobserved heterogeneity is taken into account for males but insignificant for females. They are similar across the quantiles for males but, smaller at the top than at the bottom of the conditional wage distribution for females. We further examine the public sector wage gap over time and in different sub-groups according to age and education. The public sector wage penalty for males has decreased recently over time and is larger for the better educated and younger. We also find substantial regional differences in public sector wage gap for males.
\end{abstract}

\section{JEL: C21, C23, J16, J31, J45}

Keywords: Public Sector, Private Sector, Wage Gap, Gender, Sample Selection, Quantile Regression, Panel Data, Egypt

- *This research has benefited from a financial grant from the Economic Research Forum (ERF). The contents and recommendations do not necessarily reflect the views of the ERF. We are grateful to an anonymous referee of the ERF and Insan Tunali for insightful comments on an earlier version of this paper. Any remaining errors are responsibility of our own. 


\section{1) Introduction}

For many years it was government policy in Egypt to provide employment for graduates in the public sector. There are many studies on the causes and consequences of this policy. This policy was abandoned in the early 1990s. Further, the public sector employment is being retrenched in Egypt since the early 1990s due to extensive privatizations. The competitive labor market paradigm does not relate to the public sector employment. The working conditions, retirement provisions and other benefits are thought to be better in the public sector than in the private sector. For this reason, public versus private sector wage gap is of utmost importance to the policy makers. Further, public sector pay is believed to influence the private sector pay. Institutional characteristics may influence the public and private sector pay gap. They may include the minimum wage, wage indexation, employment protection legislation and strength of unionization. Such institutional factors may not be relevant for the Egyptian labor market. However, the level of centralization of the public sector is strong in Egypt.

Recently, Assaad (1997) and Said (2015) have investigated the earnings in the public sector in Egypt. However, this is the first study that explicitly investigates the public versus private earnings differential in Egypt using panel data which is rare in developing countries. We examine the cases of females and males separately during the 1998-2012 period using the Egyptian Labor Market Panel Survey. We estimate Mincer wage equations both at the mean and at different quantiles of the wage distribution taking into account observable and unobservable characteristics with a fixed effects model. We first provide an application of quantile regression of the wage equations with sample selection correction. Upon finding that there is very little evidence of sample selection in our data we then turn to further estimates without sector selection correction. We find a persistent public sector wage penalty for males and public sector wage premium for females. They are larger when unobserved heterogeneity is taken into account for males but insignificant for females. They are similar across the quantiles for males but, smaller at the top than at the bottom of the conditional wage distribution for females. In addition, we also examine the public versus private sector earnings differential over time as well as for the different sub-groups of the population according to age, education and region of residence. The public sector wage penalty for males has decreased recently over time and is larger for the better educated and younger. There are also significant regional differences. 
This paper is organized as follows. Section 2 gives a brief review of literature. A brief background on Egyptian labor market is provided is Section 3. Section 4 explains the data used and the descriptive evidence. The methodology and the empirical strategy followed are described in Section 5. Estimation results with sample selection correction are discussed in Section 6. Section 7 presents the estimation results without the sample selection correction. Concluding remarks appear in Section 8.

\section{2) Brief Review of Literature}

Gregory and Borland (1999) provide a thorough review of literature on public sector labor markets. The vast majority of the public-earnings gap literature concentrates on crosssectional differences in wages. Most studies also address the non-random sector selection. Such studies include Hartog and Oosterbeek (1993) and van Ophem (1993) for the Netherlands, Lassibille (1998) for Spain, Dustmann and van Soest (1998) and Melly (2005) for Germany, Disney and Gosling (2003) for the UK, Tansel (2005) for Turkey and Bargain and Melly (2008) for France. Lucifora and Meurs (2006) measure and decompose public-private earnings differences in the UK, France and Italy. For France and Italy they conclude that in the private sector the use of collective bargaining and union power are substantial. This results in a pay setting system based heavily on rewarding observable characteristics such as education and experience. This can explain the substantial part of public sector earnings gap. Their results of quantile regression analysis is similar to Melly's findings for Germany. They find that as one moves up the earnings distribution, the proportion of the pay gap explained by observable factors increases. In contrast, in the lower quantiles differences in unobserved characteristics are more important in explaining pay differences. Similar results for France and Italy are also found by Ghinetti and Lucifora (2007) using European Community Household Panel data from the 2001 wave. Van Ophem (1993) uses functional form assumptions to deal with the sector selection issue. Dustmann and van Soest (1998) and Hartog and Oosterbeek (1993) use an instrumental variables approach. Further they consider only cross-sectional differences in instantaneous earnings between the public and private sectors.

Cappellari (2002) and Postel-Vinay and Turon (2007) are the only studies that address differences in earnings dynamics between the public and private sectors. Capellari uses a panel of Italian administrative data and assumes exogenous selection of individuals into sectors. $\mathrm{He}$ 
also contributes on empirical models of income dynamics and study of lifetime income inequality. Heitmueller and Mavromaras (2007) study the public-private sector pay gap in Germany in the 1990s. They find that throughout the 1990s the pay gap remained stable in the West and increased considerably in the East which is an indication of the public sector crowding out the private sector in the East.

Dell'Aringa, et al. (2007) investigate regional public-private wage gap in Italy using geographically weighted regressions. They find that the pay gap can be partly explained by local labor market conditions affecting the private sector and only marginally the public sector. The regional pay gaps are found to explain regional imbalances in terms of 'wait' unemployment and regional recruitment problems. Garcia-Perez and Jimeno (2007) also investigate wage differences among regions using data from the European Community Household Panel for the period 1995-2001. They find that the public sector wage gaps vary across gender, educational levels and occupations.

Cai and Liu (2011) examine the public-private wage gap along the wage distribution employing quantile regressions. The pay gaps decrease monotonically and are negative at the top half of the distribution for males while pay premiums are relatively stable across the distribution for females. Giordano et al. (2011) use the 2004-2007 SILC data for 10 European Union countries. They find a public sector premium in most countries. Campos and Centeno (2012) analyze the evolution of public wages and the public-private wage gaps in several European countries using fixed effects quantile regressions. They find that the public-private pay gap increased in the 1990's favoring the public sector employees compared to private sector employees with the same observable and unobservable characteristics. Siminski (2013) investigates the public-private wage gap for Australia across the wage distribution with significant premium for women but not for men. He finds that the compressed wage profile of the public sector induces the best workers (on unobserved skills) to join the public sector in both high and low wage occupations. Christofides and Michael (2013) estimate the public versus private pay gap for 27 European countries using the 2008 SILC data. They account for selectivity and decompose into explained and unexplained components. The QR estimates show that public-private wage gap is generally larger at the bottom than at the top of the wage distribution. 
Nikolic (2014) investigates the public-private pay gap in Serbia with significant changes over the 1995-2008 period. He finds negative pay gaps at early stages of economic transition but positive ones during large-scale privatizations. Lausev (2014) surveys the literature on public-private pay gap in transitioning countries of Eastern Europe and compares the results with those from developed countries. He finds public sector pay penalties during the period of economic transition from a communist to market-based economy as compared to zero or positive pay gap in developed economies. He also concludes that the competition for workers is the major cause of the systematic pay differences between the two sectors.

Christopoulou and Monastiriotis (2014) study the public-private pay gap in Greece. They find a large public premium which is mostly accounted for by self-selection into the sector that rewards better their characteristics for men, while it is due to public-private differences in returns for women. Depalo et al. (2015) consider the euro-area and provide quantile decompositions. Hospido and Moral-Benito (2016) examine the Spanish pay gap utilizing data from tax records. They find a public sector premium which also varies along the wage distribution after accounting for characteristics and endogenous selection. Mahuteau et al. (2017) examine the case in Australia using a panel data quantile regression with fixed effects controlling for observable and un-observable factors. They find a public sector premium which is slightly higher for females than for males. This impact is larger at the lower end of the wage distribution than at other parts.

\section{3) Egyptian Public and Private Labor Markets}

Tansel and Ozdemir (2014) and Tansel et al. (2015) provide a recent review of the Egyptian economy and the labor market. This section will give a brief overview of the Egyptian public and private labor market. According to the Egypt Labor Market Panel Survey (ELMPS) 2012, the government employment is about 24 percent among men and 12 percent among women. According to recent statistics public sector employs 27 percent of all workers and 44 percent of the wage earners (Amin, 2014). Women out of the labor force are substantial. About 10 percent of men and 72 percent of women are out of labor force (Tansel and Ozdemir, 2014). During the past two decades substantial labor retrenchment took place in the public sector. Therefore, the government employment opportunities have been declining recently. Public administration lost about 40,000 jobs during the 2006-2012 (World Bank, 2014). However, government employment is a more attractive employment option in particular for women than 
private sector jobs. Individual self-employment and employment in household enterprises constituted more than a third of overall employment in 2006. Nearly half of private sector wage employment was in micro enterprises of fewer than five workers (Said, 2009). Therefore, informal employment is rather large with strong segmentation as noted by Gatti et al. (2014). Tansel et al. (2015) find large informal sector penalty in earnings vis-à-vis the formal sector in Egypt.

Female labor force participation is very low in Egypt. It was 23.1 percent for females and 80.2 percent for males in 2012 (Assaad and Krafft, 2013). The 15-29 year olds constitute about a quarter of the total labor force. Unemployment rate was about 12.6 percent in 2016 and higher for females than for males (CAPMAS, 2014). Almost over 75 percent of the unemployed was 15-29 years old implying an unemployment problem for the youth. The unemployment rate is also rather high among the highly educated (Assaad and Krafft, 2013). Thus, although their labor force participations are very low, women and the young exhibit high unemployment rates. Labor legislation mainly effects small number of wage and salary workers in the private formal sector, civil servants and public sector. Labor law in Egypt might be considered rigid de jure, by international standards but, they are not enforced de facto (AngelUrdinola and Kuddo, 2011). Thus enforcement remains weak (Lohmann, 2010). The trade union membership is weak (Angel-Urdinola and Kuddo, 2011). The trade union density rate in 2007 as a proportion of total employment was 16.1 and as a proportion of wage and salary earners was 26.1. Collective bargaining coverage in the private sector is limited. The minimum wage law is effective only in the public sector. It was adjusted twice recently; in 2012 for the first time since the 1980's and then in 2014.

Recently, there was a trend toward greater formalization in private wage employment (Said, 2009). However informal employment has increased recently due to the privatization along with a decline in public sector employment opportunities and the introduction of the 2003 Labor Law. The 2003 Labor Law brought more flexibility in employment relations which is believed to cause an increase in informal employment yet at the same time contributed to formalization since then (Wahba and Assaad, 2015). However, World Bank (2014) notes a recent increase in informality across nearly every industry and at all education categories for men. 
Assaad (2009) and Said (2009) express concern about recent high unemployment rate among the university graduates. Their another concern is the recent declining participation rates of educated females who drop out of the labor force when discouraged due to lack of government employment opportunities

\section{4) The Data and the Descriptive Evidence}

This study is based on the longitudinal survey of Egypt Labor Market Panel Survey (ELMPS) carried out in 1998, 2006 and 2012. The surveys are publicly available in the Economic Research Forum (ERF) web page free of charge. The surveys were implemented by the ERF in cooperation with Egypt's Central Agency for Public Mobilization and Statistics (CAPMAS). These nationally representative surveys cover a wide-range of topics including individual, demographic and labor market characteristics, parental background, time use and fertility among others. The 1998 round includes a sample of 4,816 households and 23,997 individuals. The 2006 round, located 3,685 households from the 1998 round. A refresher sample of 2,498 households were added giving a total of 37,140 individuals in the 2006 round. The 2012 round interviewed households from the 2006 and 1998 rounds. A refresher sample of 2,000 households were added giving a total of 49,186 individuals in the 2012 round. Attrition both at the household and individual levels are discussed by Assaad and Krafft (2013) extensively. They note that the attrition was mostly random from 1998 to 2006 but "complex in nature" from 2006 to 2012. They correct for the attrition using nonresponse weighs which are computed with observable characteristics of individuals and households. These weights are used to adjust for the attrition in the descriptive statistics in Table 1-a-b-c-d of this paper. Assaad and Krafft also evaluate the representativeness of the ELMPS by comparing it to labor force surveys for Egypt. The panel data are five or seven years apart. Workers are observed twice or three times in two-year panels of 1998-2006 and 2006-2012 and a three year panel of 1998-2006-2012.

We restrict the sample to 15-65 year old wage earners in each sample separately. Those who are in education or training are excluded. Unpaid family workers (UFW) are also excluded since their imputable earnings are not observed. The formal private sector includes nonagricultural, full-time wage-earners who work 30 hours or more per week. The real hourly wages are reported in the data set and computed as the monthly wages per hour of work in the primary and secondary jobs deflated by the CPI base 2012. The wage determination 
mechanisms differ vastly across public and private sectors. In order to make the public and the private sector samples comparable in terms of their non-monetary remunerations we consider the formal private sector wage-earners and ignore informal private sector wage earners. The sectors are defined such that they are comparable along a number of dimensions. We define formal private sector (henceforth private sector) as those wage earners who are covered by the social security through their employment and/or who have an employment contract. Our definition of public (or government) sector (henceforth public sector) excludes public enterprise workers. In the data set the mean log hourly wage of public enterprise workers is 1.73 while that of the government employees is 1.53 . Their difference is statistically significant at the one percent level. Therefore public enterprise workers are excluded in order not to confound the results.

Male and female samples are analyzed separately. The labor force participation of women in Egypt is very low. Most of the women are either inactive or work as unpaid family workers (Tansel and Ozdemir, 2014). Therefore, the issues of women's selection both into employment and the public-private sector are important to address. This is not a standard econometric procedure in the QR framework. We address the sector selection issue in our QR estimation. Further, the number of female observations in the private sector is rather small. Therefore, in the following sections some of the estimation procedures are not performed for the female sample. In such cases we report and comment on the estimates only for the male sample.

\section{\# Insert Figure 1 about here \#}

Figure 1 shows the Kernel density estimates of the log hourly wages in the public and private sectors. The non-parametric Kolmogorov-Smirnov test indicates that the null hypothesis of the sectoral log hourly wages come from the same distribution is rejected at the five percent level of significance in all cases except for females in 1998 and males in 2006. For females in 2006 and 2012 the distribution of the public sector wages dominate that of the private sector. Public sector Kernel density stand to the right of the private sector Kernel density indicating that public sector wages exceed that of the private sector throughout the distribution. For males in 1998 private sector Kernel density stands slightly to the right of the public sector density indicating some public sector penalty in the middle of the distribution. In 2012 the public sector Kernel density stands slightly to the right of the private sector density indicating 
some public sector premium.

Tables 1-a-b-c-d gives the descriptive statistics for the female and male samples in the public and private sectors for 1998, 2006, 2012 and for the pooled sample respectively. The figures in these tables are adjusted for attrition. the In Table 1-a for 1998, female log hourly wage in the public sector is higher than that of the male while in the private sector male log hourly wage is higher than that of the female. Further, male mean log hourly wage is higher in the private than in the public sector while opposite hold true for the female log hourly wage. The female log hourly wage in the public sector is higher than in the private sector. In 2006 the mean log hourly wages are higher than in 1998 and the standard deviations are also higher. This implies higher wage inequality in 2006 compared to in 1998. The relative sizes of the public versus private sector mean log hourly wages are similar to those observed in 1998. In 2012 the mean log hourly wages are higher than in 2006. The standard deviations of log hourly wages in 2012 is less than that in 2006.This implies smaller wage inequality in 2012 compared to in 2006. In the public sector, contrary to that in 1998 and 2006, the male mean log hourly wage is higher than that of the female. In the private sector, similar to 1998 and 2006, the male mean log hourly wage is higher than that of the female. Further, for males contrary to that in 1998 and 2006, male mean log hourly wage in the public sector is higher than that of in the private sector. Similar to that observed in 1998 and 2006, the female log hourly wage in the public sector is higher than that in the private sector.

Finally the Table 1-d gives the descriptive statistics for the pooled sample. For men the mean $\log$ hourly wage is larger in the private sector than in the public sector while the reverse is true for women where the mean log hourly wage is substantially larger in the public sector then in the private sector. These indicate a public sector penalty for men but a public sector premium for women. We comment on the rest of the variable in Table 1-d. The weekly hours of work is substantially larger in the private sector than in the public sector especially for females. Both females and males are substantially older in the public than in the private sector. In both the public and private sectors, women are better educated than men since the female years of schooling are larger than that of males in both sectors. Further, men are somewhat better educated in the public than in the private sector whereas females are equally well educated in both sectors. A larger percentage of both females and males in public sector are married than in the private sector. Similarly, a larger percentage of both females and males in the public sector have children. The Rural Upper region has the least percent of female public employees. 
Nearly half of the female private sector employees are in the Greater Cairo region. As remarked earlier, the total number of female observations in the private sector is rather small. This has created problems in some estimation procedures.

Above explanations refer to the raw differences between the public versus private sectors. However, the compositional differences in the characteristics of public versus private sector employment are important. For the public sector the educational threshold is higher. Employment entry age is also higher. There is greater representation of women in the public than in the private sector. In the rest of this paper we consider the pay gap by controlling for the compositional differences between the public and private sectors.

\section{\# Insert Tables 1-a-b-c-d about here \#}

\section{5) Conceptual Framework and the Econometric Methodology}

Recently panel data became available in many developing countries. In particular, with the panel data, estimation of fixed effect (FE) model, that is purging of the effect of unobservable characteristics became possible. The FE estimation deals with the issue of unobservable characteristics providing consistent estimates assuming that un-observables are time invariant. A number of researchers followed this route in studying wage differential between formal versus informal sectors both at the mean and at various quantiles. They include, Tansel and Kan (2012) in Turkey, Nguyen et al. (2013) in Vietnam, Bargain and Kwenda (2014) in Brazil, Mexico and South Africa, Tansel et al. (2015) in Egypt and Nordman et al. (2016) in Madagaskar. A common finding is that sectoral earnings differentials either get smaller or disappear in these countries when unobservable worker characteristics are controlled for with FE estimation exploiting the panel feature of the data. Mahuteau et al. (2017) for Australia address the public versus private wage differential employing panel data with a FE model both at the mean and across the wage distribution. None of these studies addressed the issue of sector of employment selection as we consider in this paper.

Earlier studies in the literature on the sectoral earnings differentials focused on estimation at the mean of the earnings distribution. There may be important differentials along the earnings distribution due to intrinsic heterogeneity in jobs. This is ignored when only the differential at the mean is considered. Recently, researchers addressed the heterogeneity that 
may exist along the earnings distribution by using $\mathrm{QR}$ technique in various contexts. For example, Botelho and Ponczek (2011) in Brazil provided estimates along the earnings distribution in the context of formal versus informal sectors. However, while employing QR estimation addressing of the estimation problems such as unobserved heterogeneity or sector selection becomes difficult. The techniques to deal with these problems are theoretically well developed and available but their implementation are rare. Tannuri-Pianto and Pianto (2002) adopt the QR technique corrected for self-selection using instrumental variables (IV) with a cross-sectional data set in Brazil. Tansel et. al. (2015) in Egypt, Nguyen et al. (2013) in Vietnam, Bargain and Kwenda (2014) in Brazil, Mexico and South Africa and Mahuteau et al. (2017) in Australia adopt a fixed effect model estimation with QR technique (FEQR). Instrumental variable (IV) methods could be useful in addressing the sector selection issues and in order to obtain causal estimates. However, a suitable instrumental variable could not be found in the ELMPS. Therefore, in this paper this method is not employed. We address the sample selection issue that influences the decision to seek public sector employment.

We first estimate several models with sample selection correction. First, we use the standard Heckman selection correction with a probit sector of employment selection in the first stage and an Ordinary Least Square (OLS) public and private wage equations in the second stage. Second, we estimate Fixed Effects (FE) model at the mean with sample selection. Third, we estimate a QR model with sample selection correction. Unfortunately, we cannot carry out a Fixed Effects Quantile Regression (FEQR) model with sample selection correction, because to the best of our knowledge the theoretical developments in the estimation of this model is not treated.

In our estimates of various models with sample selection correction, presented in Section 4.1, we find that the sample selection term is mostly statistically insignificant. This indicates that the non-random sample selection between public and private sectors is not important in our data. In the face of this finding our preferred estimates are those without sample selection correction. These estimates include utilization of OLS, FE, QR and FEQR techniques. They are explained in Section 4.2. The conceptual framework is based on the Mincer earnings equation. It is estimated with a dummy variable indicator for the public sector. Namely, we consider the earnings gap for the two sectors and ascertain whether this gap favors public sector or the private sector. We carry out the estimations at the mean of the wage distribution and at 
various quantiles of the conditional wage distribution. In this process we employ the OLS, FE QR and FEQR techniques.

\section{1) Models with Sample Selection Correction}

Heckman two-step method involves two steps. In the first step we estimate a simple probit model for the probabilities of workers selecting public or the private sector. In the first step we estimate the probit equation by maximum likelihood method and compute the Inverse Mills Ratio (IMR). In the second step we estimate the wage offer equation by OLS by including the IMR as an additional variable. Our second set of estimates are FE estimates with sample selection correction. In this process we use the panel feature of the data. We first estimate a panel probit model and compute the IMR. In this process we use a Random Effects (RE) model. In the estimation of the wage equation, we perform a Hausmann test of whether FE or RE estimation is suitable. The test results indicated that FE model is preferable. Therefore, in the second step we estimate a FE model of the wage equation expanded with IMR

Our third set of estimates are QR estimates with sample selection correction. There are very few applications of this method. We have located the applications by Buchinski (2001), Tannuri-Pianto and Pianto (2002), Huber and Melly (2011) and Coelho et.al. (2008). The method is developed by Buchinsky (1998) based on non-parametric method. This is a variant of the standard Heckman two-step estimation method developed for the mean regression by Heckman (1979) and extended by Newey (1999). In the first step, we use a model similar to probit model for sector selection but rather than assuming normality we use the semi-parametric method developed by Ichimura (1993) called Semi-Parametric Least Squares (SLS). The estimates are consistent and asymptotically normal. Following Buchinsky (1998), in the second step the quantile wage equation is expanded with power series expansion of IMR in order to control for sector selection. Details of this procedure are given in Buchinski (1988; 2001) and Tannuri-Pianto and Pianto. We provide a summary of this procedure in AppendixB.

\section{2) Models without Sample Selection Correction}

The OLS model is estimated on a sample of pooled panel observations of individualyear pairs as follows. 


$$
y_{i t}=\delta I_{i t}+x_{i t}^{\prime} \beta+\varepsilon_{i t}
$$

We correct the standard errors to reflect the fact that we use observations from the same person are used two or three times. Next we use panel feature of the data and estimate a FE model where we control for time-invariant unobserved individual heterogeneity. The FE estimator is consistent as long as unobserved characteristics are constant over time. The FE model is specified as follows.

$$
y_{i t}=\delta I_{i t}+x_{i t}^{\prime} \beta+\alpha_{i}+\varepsilon_{i t}
$$

In models (1) and (2) $y_{i t}$ is log hourly wages, $x_{i t}$ is the vector of control variables for individual $i$ at time $t$ including a constant, $I_{i t}$ is a dummy variable taking a value one if the wage earner is in the public sector at time $t$. The private sector worker is the base category. $\alpha_{i}$ is the individual fixed effect. $\varepsilon_{i t}$ is a normally, independently and identically distributed stochastic error term with zero conditional mean. The estimated $\delta$ measures the public employment penalty/premium.

Next we investigate the public sector wage penalty/premium along the conditional wage distribution using QR. The standard QR method is then extended to using panel data and we estimate the FEQR model. Estimating the QR models are especially important since the conditional earnings differentials across different quantiles proxy for unobservable earnings potential. The QR and FEQR models can be written as in equations (3) and (4) as follows respectively.

$$
\begin{aligned}
& q_{\tau}\left(y_{i t}\right)=\delta(\tau) I_{i t}+\lambda(\tau) G_{i t}+x_{i t}^{\prime} \beta(\tau)+\varepsilon_{i t}, \quad \forall \tau \in[0,1] \\
& q_{\tau}\left(y_{i t}\right)=\delta(\tau) I_{i t}+x_{i t}^{\prime} \beta(\tau)+\alpha_{i}+\varepsilon_{i t}, \quad \forall \tau \in[0,1]
\end{aligned}
$$

Where, $q_{\tau}\left(y_{i t}\right)$ is the $\log$ hourly wages at the $\tau^{\text {th }}$ quantile. $\alpha_{i}$ are the individual fixed effects that shift the location of the conditional quantiles in the same manner across the quantiles. However, the effects of the explanatory variables differ by the quantiles considered. The vector of estimated coefficients $\beta(\tau)$ provide the estimated rates of return to the different covariates 
at the $\tau \%^{\text {th }}$ quantile and the estimated coefficient $\delta(\tau)$ represents public sector wage penalty/premium at the various quantiles. The FEQR technique was first suggested by Koenker (2004) as a direct extension of the standard QR method. However it was Canay (2011) who provided an implementation procedure. He suggested a simple two-step approach for FEQR estimation. In the first step the individual effects are estimated by traditional mean estimations such as FE estimation. The individual fixed effects are pure location shifters. Then predicted individual effects are used to correct earnings as in $\hat{y}_{i}=y_{i}-\hat{\alpha}_{i}$. The corrected earnings are then used in the traditional QR estimation.

In all of the model specifications given above following control variables are used. Age, age squared, years of education, marital status, presence of children, sectors of economic activity, regions of location and time dummies for survey waves. The time indicators for 2006 and 2012, control for the effect of macroeconomic environment on wages over the survey years. The base year is 1998. The effects of differences in the structure of sectors on wages are considered by including dummies for the five sectors of economic activity. They are manufacturing (including mining and electricity), construction, trade, transportation, and services (including finance). The base sector is manufacturing. The six regions of residence are Greater Cairo, Alexandria and Suez, Urban Lower, Urban Upper, Rural Lower and Rural Upper. The base region is Greater Cairo.

\section{6) Estimation Results with Sample Selection Correction}

Table 2 presents the probit and panel probit estimates of employment sector selection. These are first stage estimates. Using these results we subsequently present the selectivity corrected wage equation estimates in Table 3 by including IMR as an additional variable. Table 2 estimates include other-public, other-private, marital status and number of children as the identifying variables of the probit models. Other-public is the number of household members working in the public sector other than the individual her/himself. Other-private is the number of household members working in the private sector other than the individual her/himself. In both the probit and panel probit estimates other-public and other-probit variables are statistically significant with positive and negative signs respectively. Presence of other household members working in the public sector increases the individual's probability of working in both the public and the private sectors. Presence of other household members 
working in the private sector increases the individual's probability of working in both the public and the private sectors. These variables achieve the identification of the sector of employment selection. Individual's being married is statistically significant only in the female sample.

\section{\# Insert Table 2 about here \#}

Table 3 presents the Mincer wage equations with selection correction by gender in the OLS (standard Heckman) models and in the FE models. The estimates of the selection term, lambda, are all statistically insignificant except for males in the FE estimates of the public sector indicating a negative selection into the public sector for males. Age and age-squared are mostly statistically significant with positive and negative signs respectively. Years of schooling are all significant in the OLS estimates indicating similar returns to schooling for females in the public and private sectors. For males the returns to schooling are higher in the public than in the private sector. In the FE estimates the returns to schooling are similar in the public and private sectors for females but insignificant for males. The insignificance of lambda in these estimates leads us to conclude that sector selection is not important issue in our sample.

\section{\# Insert Table 3 about here \#}

Table 4 presents the Semi-Parametric Least Squares (SLS) estimates of the employment sector choice by gender. The models are identified by including following variables as defined above. They are other-public, other-private, married and number of children. The probability of working in the public sector first increases then decreases with age both in the public and private sectors for both males and females (insignificant). Years of schooling increases the probability of working in the public sector for both females and males. The other-public increases the probability of working in the public sector and decreases the probability of working in the private sector for males. For females this variable increases both the probability of working in the public sector and the private sector (insignificant). For females being married increases the probability of working in the public sector but decreases the probability of working in the private sector. For males being married reduces the probability of working in the public sector and the private sector (insignificant). For females the number of children reduces the probability of working in both the public (insignificant) and the private sectors. For males it increases the probability of working in both the public and private sectors. The presence 
of public sector employment decreases in 2006 and 2012 compared to 1998 which is expected due to recent public sector retrenchment.

\section{\# Insert Table 4 about here \#}

In the second step QR models with selection correction are estimated. The IMR polynomials from the first stage SLS estimates are included as additional regressors. Table 5 for females and Table 6 for males present the QR estimation of the selection corrected wage equations. For females the selection term, lambda, is statistically significant only in the q10 and q25 the lower two quantiles. This leads us to conclude that selection term is mostly insignificant and therefore not important in our data. There is positive selection to the public sector in the lowest two quantiles. Selection to the private sector is insignificant. For males there is negative selection to the public sector and the private sector in the upper quantiles of the conditional wage distribution. The positive selection term for females at lower quantiles imply that females receive higher wages at the public sector at low wages than one would expect based on their observable characteristics. At the private sector at all quantiles workers earn as much as expected based on their observable characteristics. The negative selection terms at upper quantiles for males imply that high income public sector workers earn less than one would expect based on their observable characteristics. Similarly for the private sector workers in the sense that there is negative selection in the private sector well.

\section{\# Insert Table 5 about here \# \# Insert Table 6 about here \#}

The coefficient estimate of the years of schooling are statistically significant at all quantiles for both females and males. They are higher for low wage individuals. They indicate a returns to schooling of around $7-8 \%$ for the females which is decreasing across the quantiles. And about $6 \%$ for males which is somewhat lower than for females in both the public and private sectors.

\section{Oaxaca- Blinder Decomposition:}


Table 7-a shows the Oaxaca-Blinder decomposition of public-private wage differentials by gender and male-female wage differentials by sector of employment. In the case of differentials between sectors of employment the observed and unobserved components are larger for males than for females. For both females and males the unobservable components are larger than the observable components. For males the unobservable component favor the private sector. In the case of the differential between male and female workers the observable components favor females. The unobservable component for females is larger than that of the males. Table 7-b shows the decompositions by quantiles with and without sample selection correction.

\section{\# Insert Table 7-a-b about here \#}

\section{7) Estimation Results without Sample Selection Correction}

\section{1) Main Results}

The main estimation results are summarized in Table 8. These are based on the full estimation results presented in the Appendix-A. We first discuss the results for males. Most of the coefficient estimates are statistically significant at one percent level. The OLS estimate indicates a statistically significant public sector penalty of about 14 percent. The Quantile Regression (QR) estimates also indicate statistically significant penalties except at the lowest quantile. The penalties increase in magnitude across the quantiles. The next row in this table gives the Fixed Effect (FE) and the Fixed Effect Quantile Regression (FEQR) estimates where the unobservable factors are taken into account in addition to the observable ones. The FE estimate shows a public sector penalty of about 28 percent which is much higher than the OLS estimate. In contrast Mahuteau (2017) find a smaller public sector premium with FE estimation than with the OLS. The FEQR estimates are also larger than the QR estimates. They are rather stable across the quantiles around 22-30 percent. Mahuteau et al. find slightly higher premium for women than for men and their FEQT estimates indicate a larger premium at the bottom than at the top of the wage distribution.

\section{\# Insert Table 8 about here \#}

Next we discuss the results for females. Most coefficient estimates are statistically significant. These results indicate a public sector premium. OLS gives a statistically significant premium of about 11 percent. The $\mathrm{QR}$ estimates indicate a decrease in the premium across the quantiles from about 18 percent at the bottom quantile to about 14 percent at the median. The 
top two quantiles are not statistically significant indicating that at the high levels of wages the public versus private sector wages do not differ. The FE estimate of the wage gap is not statistically significant. This implies that on average the public-private sector wages do not differ significantly when unobservable factors are controlled for.

A common finding in several studies indicate that public sector wage premium is larger at the low end of the wage distribution than at the top end of the wage distribution. For instance Birch (2006) and Cai and Liu (2011) find this for Australia with QR estimates. They also find public sector penalty for men at the top of the wage distribution. Another general finding is that public sector premium is larger for women and workers with low pay. Similar to our results Vella (1993) and Siminsky (2013) find in Australia a premium for women but no statistically significant difference for men while Cai and Liu (2011) find a premium for women and a penalty for men similar to our results for Egypt.

\section{2) Results for Various Sub-Samples}

\section{Results by Education}

The estimation results of the public sector gap for various levels of education are given in Table 9 for the male sample. Estimates for the female sample cannot be performed due to estimation problems. . For education level, less than primary, the FE estimate and of the bottom quantile is not statistically significant. The rest of the quantile estimates indicate statistically significant public sector penalties of increasing magnitude across the quantiles. For the education level of less than intermediate, the FE and the bottom quantile estimates are not statistically significant. For the rest of the quantiles there is statistically significant public sector premium of increasing magnitude across the quantiles. For the education level of intermediate and above all of the coefficient estimates are statistically significant. The FE estimate indicates a mean penalty of about 31 percent. The FEQR estimates indicate that the penalties decrease across quantiles. For the education level of university and above the FE estimate indicates a mean penalty of about 43 percent. The FEQR estimates indicate penalties of increasing magnitude across the quantiles. In general we can say that the highest penalties are observed at the highest education level of university and above.

\section{\# Insert Table 9 about here \#}


Table 10 bottom panel gives the FE and FEQR estimates for the two subsamples by education for the male sample. The estimations cannot be performed for the female sample. For the subsample of less educated where the years of schooling is less than the mean years of schooling of the sample the FE public sector wage gap is not statistically significant. The FEQR estimates all of the quantiles indicate statistically significant public sector penalty of declining magnitude across the quantiles. For the subsample of better educated where the years of schooling is greater than the mean years of schooling of the sample the FE public sector penalty is statistically significant and is about 35 percent. The FEQR estimates are all statistically significant and range between 30-37 percent. We can conclude that the public sector penalty for the better educated is much larger than for the less educated.

\section{\# Insert Table 10 about here \#}

\section{Results by Age and Time Periods}

The results by age are given in Table 10 for the male sample. We consider age as a proxy for experience. We consider two subsamples of less experienced where the age is less than the mean age and the subsample of better experienced where the age is greater than the mean age of the sample. There is statistically significant public sector penalty except in the FE estimate for the old sample. For the young the FE penalty is about 35 percent. The FEQR estimates are relatively stable across the quantiles. For the old the FE estimate is not statistically significant. The FEQR estimates are all statistically significant and somewhat increase across quantiles.

Table 10 also shows the results for the two time periods for the male sample. For the 1998-2006 time period the FE estimate is not statistically significant. The statistically significant FEQR estimates indicate relatively large public sector penalties which are more or less stable across the quantiles. For the 2006-2012 period all of the coefficient estimates are statistically significant. The FE estimates indicates a public sector penalty of about 20 percent. The FEQR estimates show that the penalty range between 19-22 percent across the quantiles. We can conclude that the public sector penalty is lower for the more recent period implying a decline in penalty over time.

\section{Results by Region}


Public sector pay gap across the regions of a country is addressed in several studies. For instance, Dell'Aringa et al. (2007) for Italy, Garcia-Perez and Jimenez (2007) for Spain and Heitmuller and Mavromaras (2007) for Germany addressed the regional public-private sector pay issues. Public sector pay is uniform across regions in Egypt due to strong central government. Therefore, the observed penalty we discuss below, is a result of the differentials across the regions in the private sector pay.

Table 11 presents the average log hourly wages by gender and region. We observe that in all of the regions the average log hourly wages for females is lower than that of males. In the male sample the average log hourly wage is highest in Greater Cairo and lowest in Rural Lower. In the female sample the average log hourly wage is also highest in Greater Cairo but lowest in Rural Upper. Table 12 presents the FE and FEQR estimates of the public versus private wage gap for the regions for the male sample. The FE estimates are not statistically significant for Greater Cairo, Alexandria and Suez Canal and Rural upper. The Table indicates a public sector penalty in all regions. These estimates are all statistically significant in all regions in all quantiles except a few in the case of Rural Upper. All of the regions exhibit a non-monotonic pattern. For the Greater Cairo the public sector penalty ranges between 12-24 percent; for Alexandria and Suez Canal it ranges between 19-30 percent; for Urban Lower it ranges between 40-53 percent; for Urban Upper it ranges between 16-26 percent; for Rural Lower it ranges between 38-47 percent and finally for Rural Upper it is about 5-6 percent when statistically significant. For the last region the estimates for the most quantiles are not statistically significant implying that the public and private sector wages do not significantly differ from each other at those quantiles for the Rural Upper. We observe that the highest penalty is at region Urban Lower. This is followed by Rural Lower. The Rural Upper exhibits the lowest public sector penalty among all of the regions. It is a general finding in the literature that public sector premium is higher in the poorer regions of the country and lower in the wealthier regions. Such findings imply that in the poor regions private sector may face difficulty in hiring high quality employees and in the wealthier regions public sector may find difficulty in retaining high quality work force. However we do not know about the wealth comparison of the regions of Egypt to make any conclusions. 


\section{\# Insert Table 11 about here \# \# Insert Table 12 about here \#}

\section{8) Conclusions}

This study investigates the public versus private sector wage gap using Egypt Labor Market Panel Survey (ELMPS) carried out in 1998, 2006 and 2012. We estimate the public and private sector wage equations using the standard Heckman model, the FE model with sample selection and with the QR model with sample selection. To the best of our knowledge we provide one of the few applications of the QR model with sample selection correction. We also present the Oaxaca-Blinder decompositions at the mean and at different quantiles. Returns to education are somewhat larger for females than for males. They decrease across quantiles for females and it is similar across the quantiles for males.

Our results for the selectivity corrected wage equations lead us to conclude that sector selection is not significant in our data. Therefore, for the rest of our study we investigate the public sector wage gap without sector selection correction. Making use of the panel feature of the data we estimate FE and FEQR whereby we take into account both the observable and the unobservable characteristics. We find significant gender differences. Our findings indicate a persistent public sector wage penalty for males and public sector wage premium for females in several alternative estimates. The public sector wage penalty for males is larger when unobserved heterogeneity is taken into account but the public sector wage premium for females becomes insignificant when unobserved heterogeneity is taken into account. The premium we find for women may be due to gender equality in pay in the public sector in Egypt and large pay discrimination for women in the private sector. The quantile regression estimates give an idea about the extent of the penalty or premium across the conditional wage distribution. The penalties for males are similar across the quantiles while premiums for females are smaller at the top than at the bottom of the conditional wage distribution. A comparison of QR and FEQR estimates imply that high paid male workers are more able in the private sector than in the public sector. A comparison of the OLS and FE estimates for men (where FE penalty is larger than the OLS) imply that private sector workers are more able than the public sector workers. Similar comparison for women (where OLS premium disappears with FE) implies that public sector workers are more able than those in the private sector. One implication is that given the 
finding of penalty for males and premium for females policy makers should set the severance payments accordingly.

We further examine the public sector wage penalty for males in different sub-samples according to education, age and time period. These subsample estimates provide interesting insight about the structure of the wages in the public and private sectors. The public sector wage penalty for males is larger for the better educated and the younger and has decreased recently over time. We also find substantial regional differences in public sector wage gap for males. The highest penalty is at region Urban Lower. This is followed by Rural Lower. The Rural Upper exhibits the lowest public sector penalty among all of the regions.

This study provides valuable information about the workings of the labor markets in the public and private sectors in Egypt. The analysis provides information about factors that underline the earnings differentials between these sectors. An understanding of these observable and unobservable factors will be useful for providing policy relevant guidelines for the administrators in the public sector employment and for the leaders of the private sector employment in Egypt.

\section{References}

Amin, G. (2014) "Egypt Country Report Policies and Mechanisms for Integration into the Workforce and Job Creation", Egypt Country Report for the 2014 Ministerial Conference on Youth Employment, How to Improve, Trough Skills Development and Job Creation, Access of Africa's Youth to the World of Work, Abidjan, Côte d'Ivoire, 21-23 July, 2014.

Angel-Urdinola, D. F. and Kuddo, A. (2011) "Key Characteristics of Employment Regulations in the Middle East and North Africa", World Bank, Washington, D.C.: World Bank. https://openknowledge.worldbank.com/handle/10986/10893.

Assaad, R. (1997) "The Effects of Public Sector Hiring and Compensation Policies on the Egyptian Labor Market", The World Bank Economic Review, 11(1), 85-118.

Assaad, R. (2009) "Labor Supply, Employment and Unemployment in the Egyptian Economy, 1988-2006", In: Assaad R (ed) The Egyptian Labor Market Revisited. Cairo, Egypt: American University in Cairo Press with Economic Research Forum, (pp.1-52).

Assaad, R. and Krafft, C. (2013) "The Evolution of Labor Supply and Unemployment in the Egyptian Economy: 1988-2012”, Cairo, Egypt: Economic Research Forum (ERF), Working Paper No: 806.

Bargain, O. and Melly, B., (2008) "Public sector pay gap in France: new evidence using panel data", IZA Discussion Paper 3427.

Bargain, O. and Kwenda, P. (2014) "The Informal Sector Wage Gap: New Evidence Using Quantile Estimations on Panel Data“, Economic Development and Cultural Change, 63(1), 117-153. 
Bender, K. A. (1998) "The central government-private sector wage differential", Journal of Economic Surveys, 12(2), 177-220.

Bender, K. A. (2003) "Examining equality between public-and private-sector wage distributions", Economic Inquiry, 41(1), 62-79.

Birch, E. R. (2006) "The public-private sector earnings gap in Australia: a quantile regression approach", Australian Journal of Labour Economics, 9(2), 99-123.

Borland, J., Hirschberg, J., and Lye, J. (1998) "Earnings of public sector and private sector employees in Australia: is there a difference?", Economic Record, 74(224), 36-53.

Botelho, F., and Ponczek, V. (2011) "Segmentation in the Brazilian Labor Market", Economic Development and Cultural Change, 59(2), 437-63.

Buchinsky, M. (1998): "The dynamics of changes in the female wage distribution in the USA: A quantile regression approach," Journal of Applied Econometrics, 13, 1-30.

Buchinsky, M., and Hunt, J., (1999) "Wage mobility in the United States", The Review of Economic Studies, 81 (3), 351-368.

Buchinsky, M. (2001). “Quantile regression with sample selection: Estimating women's return to education in the US", Empirical Economics, 26(1), 87-113.

Cai, L., and Liu, A. Y. (2011) "Public-private sector wage gap in Australia: variation along the distribution", British Journal of Industrial Relations, 49(2), 362-390.

Campos, M. M., and Centeno, M. (2012) "Public-private wage gaps in the period prior to the adoption of the euro: an application based on longitudinal data", Banco de Portugal, WP, 1, 2012.

Canay, I. A. (2011) "A Simple Approach to Quantile Regression for Panel Data", The Econometrics Journal, 14(3), 368-386.

Cappellari, L., (2002) "Earnings dynamics and uncertainty in Italy: how do they differ between the private and public sectors?", Labour Economics, 9, 477-496.

Central Agency for Public Mobilization and Statistics (CAPMAS) (2014) Statistical Year Book of A.R.E., Cairo, Egypt.

Christofides, L. N., \& Michael, M. (2013) "Exploring the public-private sector wage gap in European countries", IZA Journal of European Labor Studies, 2(1), 15.

Christopoulou, R., and Monastiriotis, V. (2014) "The Greek public sector wage premium before the crisis: size, selection and relative valuation of characteristics", British Journal of Industrial Relations, 52(3), 579-602.

Coelho, D., Soares, F., \& Veszteg, R. (2008, October). "Quantile Regression with Sample Selection: Estimating Married Women's Return of Education and Racial Wage Differential in Brazil", In XXX Meeting of the Brazilian Econometric Society.

Dell'Aringa, C., Lucifora, C., and Origo, F. (2007) "Public sector pay and regional competitiveness. A first look at regional public-private wage differentials in Italy", The Manchester School, 75(4), 445-478.

Depalo, D., Giordano, R., and Papapetrou, E. (2015) "Public-private wage differentials in euroarea countries: evidence from quantile decomposition analysis", Empirical Economics, 49(3), 985-1015.

Disney, R. and Gosling, A., (2003) "A new method for estimating public sector pay premia: evidence from Britain in the 1990s", CEPR Discussion Paper 3787.

Dustmann, C. and van Soest, A., (1998) "Public and private sector wages of male workers in Germany", European Economic Review, 42, 1417-1441.

Garcia-Perez, J. I., and Jimeno, J. F. (2007) "Public sector wage gaps in Spanish regions", The Manchester School, 75(4), 501-531.

Gatti R., D. Angel-Urdinola, J. Silva, and A. Bodor, 2014. "Striving for Better Jobs. The Challenges of Informality in Middle East and North Africa Region”. Washington, DC: World Bank, Directions in Development, No: 90271. 
Ghinetti, P., \& Lucifora, C. (2008). "Public sector pay gaps and skill levels: a cross-country comparison", (No. 118).

Giordano, R., Domenico Depalo, M., Coutinho Pereira, B., Papapetrou, E., Perez, J.,Reiss, L., Roter, M., (2011) "The public sector pay gap in a selection of euro area countries", European Central Bank Working Paper Series, no. 1406.

Gregory, R. G. and Borland, J., (1999) "Recent developments in public sector labour markets", In: Ashenfelter O, Card D (eds) Handbook of Labor Economics, 3c. Elsevier, 35733630.

Hartog, J. and Oosterbeek, H., (1993) "Public and private sector wages in the Netherlands", European Economic Review, 37, 97-114.

Heckman, J. (1979). "Sample selection bias as a specification error", Econometrica, 47: 153161.

Heitmuller, A. (2006) "Public-private sector pay differentials in a devolved Scotland", Journal of Applied Economics, 9(2), 295-323.

Heitmueller, A., and Mavromaras, K. G. (2007) "On the post-unification development of public and private pay in Germany", The Manchester School, 75(4), 422-444.

Hou, J. W. (1993) "Public-private wage comparison: A case study of Taiwan", Journal of Asian Economics, 4(2), 347-362.

Hospido, L., and Moral-Benito, E. (2016) "The public sector wage premium in Spain: evidence from longitudinal administrative data", Labour Economics, 42, 101-122.

Huber, M., \& Melly, B. (2011). Quantile regression in the presence of sample selection. School of Economics and Political Science, Department of Economics, University of St. Gallen.

Koenker, R. (2004) "Quantile Regression for Longitudinal Data”, Journal of Multivariate Analysis, 91(1), 74-89.

Ichimura, H. (1993). "Semiparametric least squares (SLS) and weighted SLS estimation of single-index models", Journal of Econometrics, 58(1-2), 71-120.

Lausev, J. (2014) "What has 20 years of public-private pay gap literature told us? Eastern European transitioning vs. developed economies", Journal of Economic Surveys, 28(3), 516-550.

Lassibille, G., (1998) "Wage gaps between the public and private sectors in Spain", Economics of Education Review, 17 (1), 83-92.

Lohmann, T. (2010) "Labor Regulation and Female Labor Market Participation A Country Study of Egypt", Regional Programme Economic Integration of Women-MENA, EconoWin,

Lucifora, C., and Meurs, D., (2006) "The public sector pay gap in France, Great Britain and Italy", Review of Income and wealth, 52 (1), 43-59.

Kanellopoulos, C. N. (1997) "Public-private wage differentials in Greece", Applied Economics, 29(8), 1023-1032.

Lucifora, C., and Meurs, D. (2006) "The public sector pay gap in France, Great Britain and Italy", Review of Income and wealth, 52(1), 43-59.

Mahuteau, S., Mavromaras, K., Richardson, S., and Zhu, R. (2017) "Public-Private Sector Wage Differentials in Australia", Economic Record, 93, 105-121.

Melly, B., (2005) "Public-private sector wage differentials in Germany: evidence from quantile regression", Empirical Economics, 30, 505-520.

Mueller, R. E. (1998) "Public-private sector wage differentials in Canada: evidence from quantile regressions", Economics Letters, 60(2), 229-235.

Newey, W. (1999) “Two step series estimation of sample selection model”, MIT. Working Paper No: 99-04. 
Nguyen, H.C., Nordman, C.J. and Roubaud, F. (2013) "Who Suffers the Penalty? A Panel Data Analysis of Earnings Gaps in Vietnam”, The Journal of Development Studies, 49(12), 1694-1710.

Nikolic, J. (2014) "The effect of large-scale privatization on public sector pay gap in a transition economy", Economics of Transition, 22(4), 759-781.

Nordman, C. J., Rakotomanana, F. and Roubaud, F. (2016) "Informal versus Formal: A Panel Data Analysis of Earnings Gaps in Madagaskar", World Development, 86, 1-17, doi:10.1016/j.worlddev.2016.05.006.

Tannuri-Pianto, M. and Pianto, D. (2002) "Informal Employment in Brazil A Choice at the Top and Segmentation at the Bottom: A Quantile Approach", Serie de Textos para Discussao No. 236, Universidade de Brasilia.

Postel-Vinay, F. and Turon, H., (2007) "The public pay gap in Britain: small differences that (don't?) matter", The Economic Journal, 117, 1460-1503.

Said, M. (2009) "The Fall and Rise of Earnings and Inequality in Egypt: New Evidence from the Egypt Labor Market Panel survey 2006", In: Assaad R (ed) The Egyptian Labor Market Revisited. Cairo, Egypt: American University in Cairo Press with Economic Research Forum, (pp. 53-85).

Said, M. (2015). "Wages and inequality in the Egyptian labor market in an era of financial crisis and revolution", The Egyptian Labor Market in an Era of Revolution, 52-69.

Siminski, P. (2013) "Are low-skill public sector workers really overpaid? A quasi-differenced panel data analysis", Applied Economics, 45(14), 1915-1929.

Van Ophem, H., (1993) "A modified switching regression model for earnings differentials between the public and private sectors in the Netherlands", The Review of Economics and Statistics, 75 (2), 215-224.

Tansel, A. (2005) "Public-Private Employment Choice, Wage Differentials and Gender in Turkey", Economic Development and Cultural Change, 53(2): 453-477.

Tansel, A. and Kan, E.O. (2012) "The Formal/Informal Employment Earnings Gap: Evidence from Turkey", Bonn, Germany: Institute for the Study of Labor (IZA) Discussion Paper No. 6556. http://ftp.iza.org/dp6556.pdf.

Tansel, A. and Ozdemir, Z. A. (2014) "Determinant of Transitions Across Formal/Informal Sectors in Egypt", Bonn, Germany: Institute for the Study of Labor (IZA) Discussion Paper No. 8773. http://ftp.iza.org/dp8773.pdf

Tansel, A., Keskin, H. I. and Ozdemir, Z. A. (2015) "Is There an Informal Employment Wage Penalty in Egypt," October, 2015, IZA Discussion Paper No. 9359. ERF Working Paper No: 976.

Wahba, J. and Assaad, R. (2015) "Flexible Labor Regulations and Informality in Egypt", Cairo, Egypt: Economic Research Forum (ERF), Working Paper No: 915.

World Bank (2014) Arab Republic of Egypt: More Jobs Better Jobs: A Priority of Egypt. Washington D.C.: Report no: 88447-EG, Poverty Reduction and Economic Management Department Middle East and North Africa Region. The World Bank. 
Figure 1: Kernel Density Estimates of Log Hourly Wage in Public and Private Sector by Gender, Egypt, 1998, 2006 and 2012.
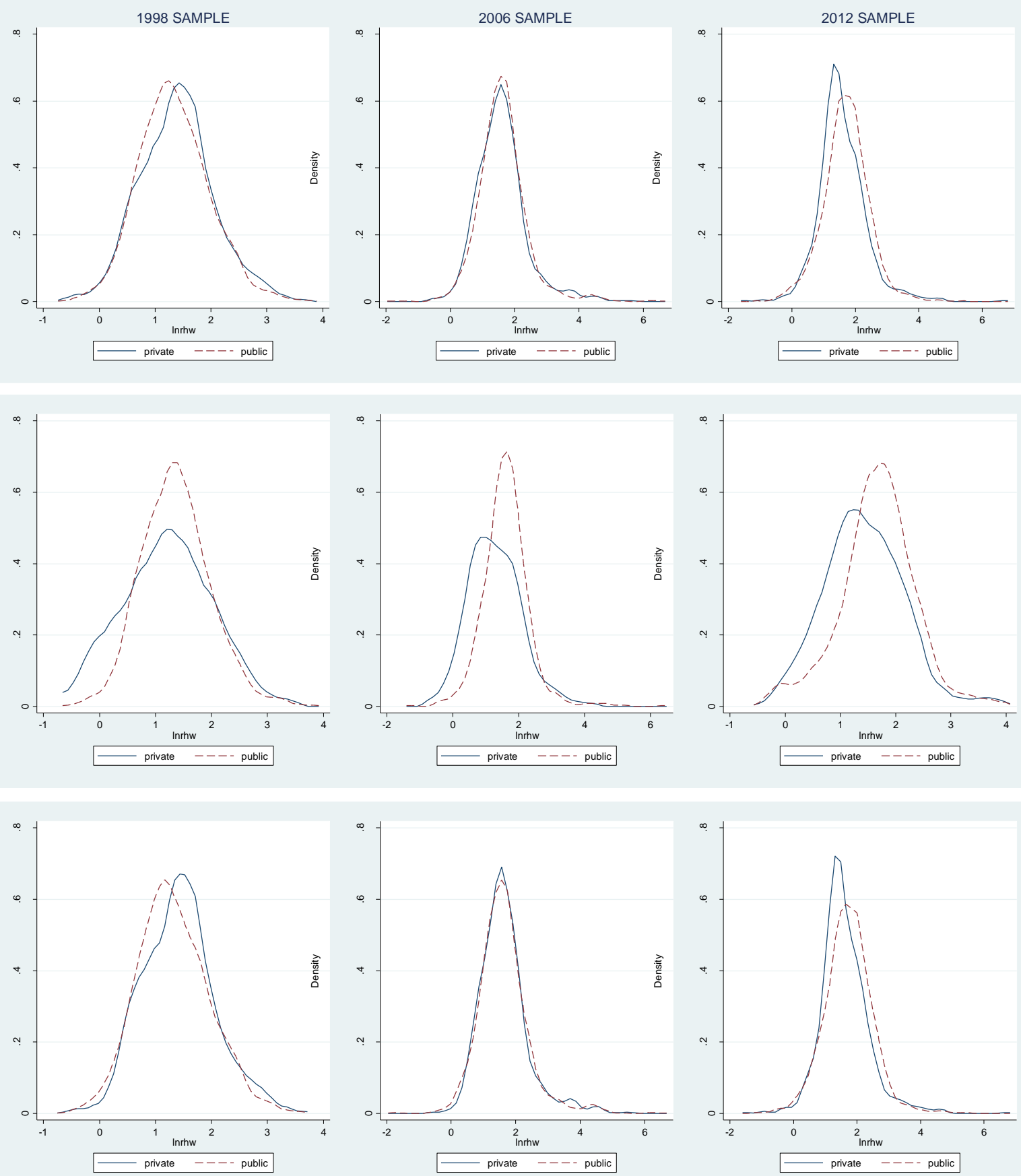

Sources: Authors' computations using ELMPS data, 1998, 2006, 2012. The top panel is for total sample. The middle panel is for the female sample. The bottom panel is for the male sample. 


\begin{tabular}{|c|c|c|c|c|}
\hline \multirow[b]{2}{*}{ VARIABLES } & \multicolumn{2}{|c|}{$\begin{array}{c}\text { Female } \\
\text { Wage Earner }\end{array}$} & \multicolumn{2}{|c|}{$\begin{array}{c}\text { Male } \\
\text { Wage Earner }\end{array}$} \\
\hline & Public & Private & Public & Private \\
\hline \multirow{3}{*}{ Log Hourly Wage } & mean & mean & mean & mean \\
\hline & 1.32 & 1.2 & 1.23 & 1.39 \\
\hline & $(0.63)$ & $(0.78)$ & $(0.63)$ & $(0.65)$ \\
\hline \multirow[t]{2}{*}{ Weekly Hours } & 38.83 & 44.84 & 49.97 & 54.96 \\
\hline & $(8.01)$ & (11.86) & $(17.20)$ & (16.77) \\
\hline \multirow[t]{2}{*}{ Age } & 37.21 & 31.45 & 41.57 & 35.01 \\
\hline & (8.93) & (10.93) & $(9.74)$ & (10.01) \\
\hline \multirow[t]{2}{*}{ Age Squared/100 } & 14.64 & 11.08 & 18.23 & 13.26 \\
\hline & $(697.31)$ & $(821.84)$ & (819.17) & (755.77) \\
\hline \multirow[t]{2}{*}{ Years of Schooling } & 13.52 & 13.35 & 10.97 & 10.02 \\
\hline & $(2.53)$ & (3.18) & $(5.01)$ & $(4.96)$ \\
\hline \multirow[t]{2}{*}{ Household Size } & 4.82 & 4.98 & 5.96 & 5.75 \\
\hline & $(1.85)$ & $(1.36)$ & (2.69) & (3.04) \\
\hline \multicolumn{5}{|l|}{ Marital Status } \\
\hline single & 20.7 & 51.2 & 14.2 & 35.3 \\
\hline married & 79.3 & 48.8 & 85.8 & 64.7 \\
\hline \multicolumn{5}{|l|}{ Children } \\
\hline no child & 27.9 & 40.5 & 21.3 & 31.1 \\
\hline with child & 72.1 & 59.5 & 78.7 & 68.9 \\
\hline \multicolumn{5}{|l|}{ Firm Size } \\
\hline $1-4$ & 15.6 & 15.6 & 25.1 & 25.1 \\
\hline $5-9$ & 10.3 & 10.3 & 10.4 & 10.4 \\
\hline $10-24$ & 15.5 & 15.5 & 15.3 & 15.3 \\
\hline $30-49$ & 8.7 & 8.7 & 8.3 & 8.3 \\
\hline $50-99$ & 19.8 & 19.8 & 8.6 & 8.6 \\
\hline More than 100 & 30.1 & 30.1 & 32.2 & 32.2 \\
\hline \multicolumn{5}{|l|}{ Sector } \\
\hline Manufacturing & 1.5 & 20.9 & 5.2 & 41.6 \\
\hline Construction & 0.1 & 5.5 & 0.2 & 8.3 \\
\hline Trade & 0.2 & 20.1 & 0.8 & 15.3 \\
\hline Transportation & 1.8 & 2.4 & 6.4 & 21.5 \\
\hline Finance and Services & 96.5 & 51.1 & 87.4 & 13.4 \\
\hline \multicolumn{5}{|l|}{ Region } \\
\hline Greater. Cairo & 22.4 & 58.1 & 14.6 & 38.1 \\
\hline Alexandria, Sz C. & 13.7 & 11.5 & 6.8 & 17.4 \\
\hline Urban Lower & 17.9 & 5.7 & 12.6 & 9.4 \\
\hline Urban Upper & 15.9 & 8.9 & 12.2 & 7.2 \\
\hline Rural Lower & 24.1 & 10.4 & 31.8 & 19.8 \\
\hline Rural Upper & 6 & 5.4 & 22 & 8.1 \\
\hline \multicolumn{5}{|l|}{ Year } \\
\hline 1998 & 93.34 & 6.66 & 78.22 & 21.78 \\
\hline Number of Obs. & 575 & 41 & 1031 & 287 \\
\hline Total Number of Obs. & \multirow{2}{*}{\multicolumn{2}{|c|}{$\begin{array}{l}616 \\
616\end{array}$}} & \multicolumn{2}{|c|}{1318} \\
\hline Total Number of ID's & & & \multicolumn{2}{|c|}{1318} \\
\hline
\end{tabular}

Source: Authors' computations using ELMPS data, 1998.

Notes: 1) The descriptive statistics in this table use the weighted observations which take attrition into account.

2) Log hourly wage is in Egyptian pounds real 2012 prices deflated using consumer price index.

3) Standard deviations are in parenthesis for the continuous variables. 
TABLE 1b: Descriptive Statistics for Public and Private Sector by Gender, Egypt, 2006

\begin{tabular}{|c|c|c|c|c|}
\hline \multirow[b]{2}{*}{ VARIABLES } & \multicolumn{2}{|c|}{$\begin{array}{c}\text { Female } \\
\text { Wage Earner }\end{array}$} & \multicolumn{2}{|c|}{$\begin{array}{c}\text { Male } \\
\text { Wage Earner }\end{array}$} \\
\hline & Public & Private & Public & Private \\
\hline \multirow[b]{2}{*}{ Log Hourly Wage } & mean & mean & mean & mean \\
\hline & $\begin{array}{l}1.64 \\
(0.72)\end{array}$ & $\begin{array}{l}1.30 \\
(0.79)\end{array}$ & $\begin{array}{l}1.60 \\
(0.79)\end{array}$ & $\begin{array}{l}1.64 \\
(0.76)\end{array}$ \\
\hline Weekly Hours & $\begin{array}{l}41.07 \\
(8.37)\end{array}$ & $\begin{array}{l}49.22 \\
(12.04)\end{array}$ & $\begin{array}{l}51.63 \\
(17.49)\end{array}$ & $\begin{array}{l}58.67 \\
(22.16)\end{array}$ \\
\hline Age & $\begin{array}{l}40.19 \\
(9.59)\end{array}$ & $\begin{array}{l}30.86 \\
(9.77)\end{array}$ & $\begin{array}{l}42.34 \\
(9.91)\end{array}$ & $\begin{array}{l}34.35 \\
(10.16)\end{array}$ \\
\hline Age Squared/100 & $\begin{array}{l}17.07 \\
(761.50)\end{array}$ & $\begin{array}{l}10.48 \\
(688.41)\end{array}$ & $\begin{array}{l}18.91 \\
(834.03)\end{array}$ & $\begin{array}{l}12.83 \\
(778.09)\end{array}$ \\
\hline Years of Schooling & $\begin{array}{l}13.61 \\
(2.93)\end{array}$ & $\begin{array}{l}12.97 \\
(3.50)\end{array}$ & $\begin{array}{l}11.73 \\
(4.82)\end{array}$ & $\begin{array}{l}10.37 \\
(4.87)\end{array}$ \\
\hline Household Size & $\begin{array}{l}4.54 \\
(1.71)\end{array}$ & $\begin{array}{l}5.06 \\
(1.85)\end{array}$ & $\begin{array}{l}5.42 \\
(2.33)\end{array}$ & $\begin{array}{l}5.11 \\
(2.42)\end{array}$ \\
\hline \multicolumn{5}{|l|}{ Marital Status } \\
\hline $\begin{array}{l}\text { single } \\
\text { married }\end{array}$ & $\begin{array}{l}22.4 \\
77.6\end{array}$ & $\begin{array}{l}62 \\
38\end{array}$ & $\begin{array}{l}12.2 \\
87.8\end{array}$ & $\begin{array}{l}32.6 \\
67.4\end{array}$ \\
\hline \multicolumn{5}{|l|}{ Children } \\
\hline no child & 40.7 & 59.2 & 26.5 & 41.6 \\
\hline with child & 59.3 & 40.8 & 73.5 & 58.4 \\
\hline \multicolumn{5}{|l|}{ Firm Size } \\
\hline $1-4$ & 6 & 6 & 28 & 28 \\
\hline $5-9$ & 5.4 & 5.4 & 8.1 & 8.1 \\
\hline $10-24$ & 23.7 & 23.7 & 11.3 & 11.3 \\
\hline $30-49$ & 18.8 & 18.8 & 9.1 & 9.1 \\
\hline $50-99$ & 11.5 & 11.5 & 10.7 & 10.7 \\
\hline More than 100 & 34.5 & 34.5 & 32.8 & 32.8 \\
\hline \multicolumn{5}{|l|}{ Sector } \\
\hline Manufacturing & 1.9 & 34.5 & 4.5 & 37.3 \\
\hline Construction & 0.1 & 2.7 & 0.6 & 7.5 \\
\hline Trade & 0.2 & 15.7 & 0.4 & 13.3 \\
\hline Transportation & 1.5 & 8.7 & 5.3 & 22.8 \\
\hline Finance and Services & 96.3 & 38.4 & 89.1 & 19 \\
\hline \multicolumn{5}{|l|}{ Region } \\
\hline Greater. Cairo & 24 & 50.5 & 16.7 & 32.5 \\
\hline Alexandria, Sz C. & 12.1 & 16 & 6.1 & 14.5 \\
\hline Urban Lower & 17.1 & 8.8 & 10.8 & 10.2 \\
\hline Urban Upper & 14.6 & 4.6 & 11 & 5 \\
\hline Rural Lower & 25.6 & 18.3 & 35.2 & 23.9 \\
\hline Rural Upper & 6.6 & 1.8 & 20.3 & 13.8 \\
\hline \multicolumn{5}{|l|}{ Year } \\
\hline 2006 & 87.88 & 12.12 & 69.26 & 30.74 \\
\hline Number of Obs. & 928 & 128 & 1719 & 763 \\
\hline $\begin{array}{l}\text { Total Number of Obs. } \\
\text { Total Number of ID's }\end{array}$ & \multicolumn{2}{|c|}{$\begin{array}{l}1056 \\
1056\end{array}$} & \multicolumn{2}{|c|}{$\begin{array}{l}2482 \\
2482\end{array}$} \\
\hline
\end{tabular}

Source: Authors' computations using ELMPS data, 2006.

Notes: 1) The descriptive statistics in this table use the weighted observations which take attrition into account.

2) Log hourly wage is in Egyptian pounds real 2012 prices deflated using consumer price index.

3) Standard deviations are in parenthesis for the continuous variables. 
TABLE 1c: Descriptive Statistics for Public and Private Sector by Gender, Egypt, 2012

\begin{tabular}{|c|c|c|c|c|}
\hline \multirow[b]{2}{*}{ VARIABLES } & \multicolumn{2}{|c|}{$\begin{array}{c}\text { Female } \\
\text { Wage Earner }\end{array}$} & \multicolumn{2}{|c|}{$\begin{array}{c}\text { Male } \\
\text { Wage Earner }\end{array}$} \\
\hline & Public & Private & Public & Private \\
\hline \multirow{3}{*}{ Log Hourly Wage } & mean & mean & mean & mean \\
\hline & 1.68 & 1.47 & 1.74 & 1.66 \\
\hline & $(0.69)$ & $(0.68)$ & $(0.74)$ & $(0.75)$ \\
\hline \multirow[t]{2}{*}{ Weekly Hours } & 37.93 & 44.97 & 49.56 & 54.14 \\
\hline & $(8.62)$ & (10.27) & (18.72) & (15.95) \\
\hline \multirow[t]{2}{*}{ Age } & 40.96 & 33.04 & 43.41 & 36.09 \\
\hline & (10.36) & $(9.85)$ & $(9.58)$ & $(9.93)$ \\
\hline \multirow[t]{2}{*}{ Age Squared/100 } & 17.85 & 11.89 & 19.76 & 14.01 \\
\hline & (847.82) & $(759.45)$ & $(819.92)$ & (789.03) \\
\hline \multirow[t]{2}{*}{ Years of Schooling } & 13.86 & 13.29 & 12.29 & 11.38 \\
\hline & $(2.52)$ & $(3.31)$ & $(4.10)$ & (4.09) \\
\hline \multirow[t]{2}{*}{ Household Size } & 4.15 & 4.25 & 4.87 & 4.33 \\
\hline & $(1.43)$ & $(1.32)$ & $(1.79)$ & $(1.57)$ \\
\hline \multicolumn{5}{|l|}{ Marital Status } \\
\hline single & 22.1 & 60.4 & 8.9 & 23.9 \\
\hline married & 77.9 & 39.6 & 91.1 & 76.1 \\
\hline \multicolumn{5}{|l|}{ Children } \\
\hline no child & 58.4 & 73.2 & 42.2 & 57.7 \\
\hline with child & 41.6 & 26.8 & 57.8 & 42.3 \\
\hline \multicolumn{5}{|l|}{ Firm Size } \\
\hline $1-4$ & 0.8 & 3.1 & 6 & 22 \\
\hline $5-9$ & 2 & 5.4 & 3 & 5.5 \\
\hline $10-24$ & 8 & 6.7 & 10.6 & 7.5 \\
\hline $30-49$ & 19.2 & 17.5 & 14.5 & 8 \\
\hline $50-99$ & 22 & 20.5 & 16.9 & 9 \\
\hline More than 100 & 47.9 & 46.7 & 49.1 & 48.1 \\
\hline \multicolumn{5}{|l|}{ Sector } \\
\hline Manufacturing & 1.9 & 26.2 & 8.2 & 36.8 \\
\hline Construction & 0 & 3.3 & 0.6 & 4.9 \\
\hline Trade & 0.8 & 7.4 & 0.8 & 14.3 \\
\hline Transportation & 0.9 & 4 & 5.6 & 17.4 \\
\hline Finance and Services & 96.4 & 59.1 & 84.8 & 26.6 \\
\hline \multicolumn{5}{|l|}{ Region } \\
\hline Greater. Cairo & 22.8 & 47.6 & 16.3 & 35.1 \\
\hline Alexandria, Sz C. & 11.4 & 20.6 & 6.7 & 14 \\
\hline Urban Lower & 16.9 & 6.1 & 11 & 10.3 \\
\hline Urban Upper & 13.8 & 4.5 & 11.8 & 6.5 \\
\hline Rural Lower & 27.3 & 16.3 & 36 & 25.4 \\
\hline Rural Upper & 7.7 & 4.9 & 18.1 & 8.7 \\
\hline \multicolumn{5}{|l|}{ Year } \\
\hline 2012 & 89.5 & 10.5 & 66.01 & 33.99 \\
\hline Number of Obs. & 921 & 108 & 1542 & 794 \\
\hline Total Number of Obs. & \multicolumn{2}{|c|}{1029} & \multicolumn{2}{|c|}{2336} \\
\hline Total Number of ID's & \multicolumn{2}{|c|}{1029} & \multicolumn{2}{|c|}{2336} \\
\hline
\end{tabular}

Source: Authors' computations using ELMPS data, 2012.

Notes: 1) The descriptive statistics in this table use the weighted observations which take attrition into account.

2) Log hourly wage is in Egyptian pounds real 2012 prices deflated using consumer price index.

3) Standard deviations are in parenthesis for the continuous variables. 
Table 1d: Descriptive Statistics for Public and Private Sector by Gender, Egypt, 1998-2012

\begin{tabular}{|c|c|c|c|c|}
\hline \multirow[b]{2}{*}{ VARIABLES } & \multicolumn{2}{|c|}{$\begin{array}{c}\text { Female } \\
\text { Wage Earner }\end{array}$} & \multicolumn{2}{|c|}{$\begin{array}{c}\text { Male } \\
\text { Wage Earner }\end{array}$} \\
\hline & Public & Private & Public & Private \\
\hline \multirow{3}{*}{ Log Hourly Wage } & mean & mean & mean & mean \\
\hline & 1.58 & 1.36 & 1.54 & 1.61 \\
\hline & 0.71 & 0.76 & 0.76 & 0.75 \\
\hline \multirow[t]{2}{*}{ Weekly Hours } & 39.35 & 46.76 & 50.49 & 56.15 \\
\hline & $(8.49)$ & $(11.51)$ & (17.83) & (19.01) \\
\hline \multirow[t]{2}{*}{ Age } & 39.7 & 31.85 & 42.45 & 35.19 \\
\hline & $(9.83)$ & (10.05) & $(9.78)$ & (10.07) \\
\hline \multirow[t]{2}{*}{ Age Squared/100 } & 16.72 & 11.16 & 18.98 & 13.39 \\
\hline & $(788.79)$ & $(743.90)$ & $(827.43)$ & $(780.73)$ \\
\hline \multirow[t]{2}{*}{ Years of Schooling } & 13.68 & 13.16 & 11.68 & 10.73 \\
\hline & (2.69) & $(3.38)$ & (4.69) & $(4.62)$ \\
\hline \multirow[t]{2}{*}{ Household Size } & 4.47 & 4.72 & 5.4 & 4.9 \\
\hline & $(1.58)$ & $(1.36)$ & $(1.54)$ & (1.61) \\
\hline \multicolumn{5}{|l|}{ Marital Status } \\
\hline single & 21.9 & 59.6 & 11.8 & 29.5 \\
\hline married & 78.1 & 40.4 & 88.2 & 70.5 \\
\hline \multicolumn{5}{|l|}{ Children } \\
\hline no child & 43.8 & 61.9 & 30 & 46.5 \\
\hline with child & 56.2 & 38.1 & 70 & 53.5 \\
\hline \multicolumn{5}{|l|}{ Firm Size } \\
\hline $1-4$ & 0.8 & 6.2 & 6 & 25 \\
\hline $5-9$ & 2 & 6.2 & 3 & 7.4 \\
\hline $10-24$ & 8 & 15.2 & 10.6 & 10.4 \\
\hline $30-49$ & 19.2 & 16.7 & 14.5 & 8.5 \\
\hline $50-99$ & 22 & 16.6 & 16.9 & 9.6 \\
\hline More than 100 & 47.9 & 39.1 & 49.1 & 39.1 \\
\hline \multicolumn{5}{|l|}{ Sector } \\
\hline Manufacturing & 1.8 & 28.9 & 5.9 & 37.8 \\
\hline Construction & 0.1 & 3.4 & 0.5 & 6.6 \\
\hline Trade & 0.4 & 13 & 0.7 & 14.1 \\
\hline Transportation & 1.4 & 5.7 & 5.7 & 20.3 \\
\hline Finance and Services & 96.4 & 49 & 87.3 & 21.2 \\
\hline \multicolumn{5}{|l|}{ Region } \\
\hline Greater. Cairo & 23.1 & 50.5 & 16 & 34.6 \\
\hline Alexandria, Sz C. & 12.3 & 17.2 & 6.5 & 14.8 \\
\hline Urban Lower & 17.2 & 7.2 & 11.4 & 10.1 \\
\hline Urban Upper & 14.7 & 5.2 & 11.6 & 6 \\
\hline Rural Lower & 25.8 & 16.2 & 34.5 & 23.8 \\
\hline Rural Upper & 6.8 & 3.7 & 20.1 & 10.7 \\
\hline \multicolumn{5}{|l|}{ Year } \\
\hline 1998 & 26 & 16.3 & 29.3 & 17.3 \\
\hline 2006 & 37.8 & 42.4 & 39.2 & 41.3 \\
\hline 2012 & 36.2 & 41.2 & 31.5 & 41.5 \\
\hline Number of Obs. & 2,424 & 277 & 4292 & 1844 \\
\hline Total Number of Obs. & \multirow{2}{*}{\multicolumn{2}{|c|}{$\begin{array}{l}2701 \\
1538\end{array}$}} & \multirow{2}{*}{\multicolumn{2}{|c|}{$\begin{array}{l}6136 \\
3780\end{array}$}} \\
\hline Total Number of ID's & & & & \\
\hline
\end{tabular}

Source: Authors' computations using ELMPS data, 1998, 2006 and 2012.

Notes: 1) The descriptive statistics in this table use the weighted observations which take attrition into account.

2) Log hourly wage is in Egyptian pounds real 2012 prices deflated using consumer price index.

3) Standard deviations are in parenthesis for the continuous variables. 
TABLE 2: Probit and Panel-Probit Estimates of Employment Sector Choice by Gender, Egypt, 1998-2012

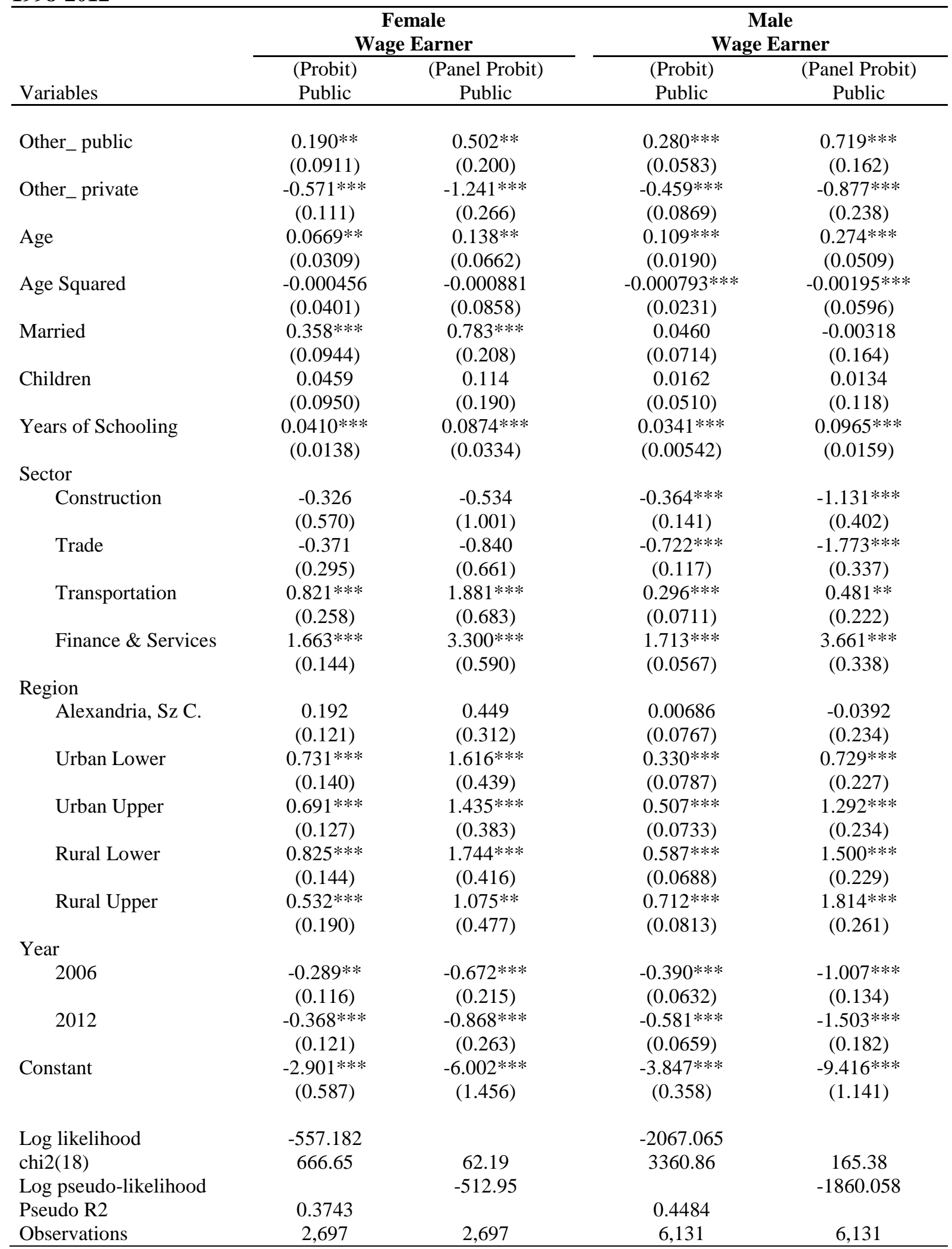

Sources: Authors' computations using ELMPS data, 1998, 2006, 2012.

Notes: 1) ***,** and * indicate significance at 1,5 and 10 percent levels respectively.

2) Robust standard errors are in parenthesis

3) Panel Probit are perform with Random Effects Probit Model, we also tested whether FE or RE model is to be preferred. However, could not perform FE Probit model with our panel data. Therefore, panel probit estimates are from RE model. 
TABLE 3: Mincer Earnings Equations with Sample Selection Correction, OLS and Fixed Effects, Egypt, 1998-2012

\begin{tabular}{|c|c|c|c|c|c|c|c|c|}
\hline \multirow[b]{2}{*}{ Variables } & \multicolumn{2}{|c|}{$\begin{array}{c}\text { Female } \\
\text { Wage Earner } \\
\end{array}$} & \multicolumn{2}{|c|}{$\begin{array}{c}\text { Male } \\
\text { Wage Earner } \\
\end{array}$} & \multicolumn{2}{|c|}{$\begin{array}{c}\text { Female } \\
\text { Wage Earner }\end{array}$} & \multicolumn{2}{|c|}{$\begin{array}{c}\text { Male } \\
\text { Wage Earner } \\
\end{array}$} \\
\hline & $\begin{array}{l}\text { (Public) } \\
\text { OLS }\end{array}$ & $\begin{array}{c}\text { (Private) } \\
\text { OLS }\end{array}$ & $\begin{array}{c}\text { (Public) } \\
\text { OLS }\end{array}$ & $\begin{array}{c}\text { (Private) } \\
\text { OLS } \\
\end{array}$ & $\begin{array}{l}\text { (Public) } \\
\text { FE }\end{array}$ & $\begin{array}{c}\text { (Private) } \\
\text { FE }\end{array}$ & $\begin{array}{l}\text { (Public) } \\
\text { FE }\end{array}$ & $\begin{array}{c}\text { (Private) } \\
\text { FE }\end{array}$ \\
\hline Age & $\begin{array}{c}0.0326^{* * * *} \\
(0.00992)\end{array}$ & $\begin{array}{c}0.0372 \\
(0.0242)\end{array}$ & $\begin{array}{c}0.0401 * * * \\
(0.00943)\end{array}$ & $\begin{array}{c}0.0515^{* * *} \\
(0.0124)\end{array}$ & $\begin{array}{l}0.0375^{*} \\
(0.0207)\end{array}$ & $\begin{array}{c}0.0471 * * \\
(0.0223)\end{array}$ & $\begin{array}{c}0.0496 * * * \\
(0.0168)\end{array}$ & $\begin{array}{c}0.0723 * * * \\
(0.0183)\end{array}$ \\
\hline Age Squared & $\begin{array}{c}-0.0000357 \\
(0.0120)\end{array}$ & $\begin{array}{l}-0.00018 \\
(0.0316)\end{array}$ & $\begin{array}{l}-0.00016 \\
(0.0105)\end{array}$ & $\begin{array}{c}-0.00046^{* * * *} \\
(0.0149)\end{array}$ & $\begin{array}{c}-0.00054^{* * * *} \\
(0.0180)\end{array}$ & $\begin{array}{c}-0.00062^{* * * *} \\
(0.0189)\end{array}$ & $\begin{array}{c}-0.00045^{* * *} \\
(0.0137)\end{array}$ & $\begin{array}{c}-0.00062^{* * * *} \\
(0.0144)\end{array}$ \\
\hline Years of Schooling & $\begin{array}{l}0.0673^{* * * * *} \\
(0.00467)\end{array}$ & $\begin{array}{c}0.0658^{* * * *} \\
(0.0114)\end{array}$ & $\begin{array}{c}0.0686 * * * \\
(0.00248)\end{array}$ & $\begin{array}{c}0.0415 * * * \\
(0.00467)\end{array}$ & $\begin{array}{l}0.0321^{*} \\
(0.0192)\end{array}$ & $\begin{array}{l}0.0351^{*} \\
(0.0196)\end{array}$ & $\begin{array}{c}-0.00101 \\
(0.0121)\end{array}$ & $\begin{array}{l}0.00689 \\
(0.0125)\end{array}$ \\
\hline Sector & & & & & & & & \\
\hline Construction & $\begin{array}{l}-0.676 \\
(0.415)\end{array}$ & $\begin{array}{c}0.558^{* *} \\
(0.258)\end{array}$ & $\begin{array}{l}0.0105 \\
(0.143)\end{array}$ & $\begin{array}{c}0.228 * * * \\
(0.0745)\end{array}$ & $\begin{array}{l}0.0834 \\
(0.598)\end{array}$ & $\begin{array}{l}0.0239 \\
(0.442)\end{array}$ & $\begin{array}{l}0.0573 \\
(0.164)\end{array}$ & $\begin{array}{l}-0.104 \\
(0.157)\end{array}$ \\
\hline Trade & $\begin{array}{l}-0.0350 \\
(0.263)\end{array}$ & $\begin{array}{l}-0.245^{*} \\
(0.128)\end{array}$ & $\begin{array}{c}-0.360^{* * * * *} \\
(0.129)\end{array}$ & $\begin{array}{l}-0.168 * * * * \\
(0.0579)\end{array}$ & $\begin{array}{l}-0.0604 \\
(0.222)\end{array}$ & $\begin{array}{l}-0.171 \\
(0.255)\end{array}$ & $\begin{array}{l}0.277^{*} \\
(0.144)\end{array}$ & $\begin{array}{l}0.0145 \\
(0.111)\end{array}$ \\
\hline Transportation & $\begin{array}{l}-0.355^{* * *} \\
(0.153)\end{array}$ & $\begin{array}{c}0.227 \\
(0.188)\end{array}$ & $\begin{array}{l}-0.0588 \\
(0.0586)\end{array}$ & $\begin{array}{l}0.183 * * * \\
(0.0476)\end{array}$ & $\begin{array}{l}-0.110 \\
(0.258)\end{array}$ & $\begin{array}{l}0.0213 \\
(0.282)\end{array}$ & $\begin{array}{l}0.0384 \\
(0.108)\end{array}$ & $\begin{array}{l}0.0690 \\
(0.109)\end{array}$ \\
\hline Finance \& Services & $\begin{array}{l}-0.335^{* * *} \\
(0.138)\end{array}$ & $\begin{array}{l}-0.248 \\
(0.184)\end{array}$ & $\begin{array}{l}-0.126 \\
(0.0876)\end{array}$ & $\begin{array}{l}0.0469 \\
(0.128)\end{array}$ & $\begin{array}{l}-0.265^{*} \\
(0.157)\end{array}$ & $\begin{array}{l}-0.0915 \\
(0.202)\end{array}$ & $\begin{array}{c}-0.303 * * * \\
(0.0996)\end{array}$ & $\begin{array}{l}0.0167 \\
(0.139)\end{array}$ \\
\hline Region & & & & & & & & \\
\hline Alexandria, Sz C. & $\begin{array}{c}-0.114 * * * \\
(0.0444)\end{array}$ & $\begin{array}{l}-0.0594 \\
(0.0982)\end{array}$ & $\begin{array}{l}-0.0443 \\
(0.0442)\end{array}$ & $\begin{array}{l}-0.0815 \\
(0.0497)\end{array}$ & $\begin{array}{l}0.0295 \\
(0.311)\end{array}$ & $\begin{array}{l}0.0605 \\
(0.534)\end{array}$ & $\begin{array}{c}0.429 \\
(0.606)\end{array}$ & $\begin{array}{c}0.379 \\
(0.607)\end{array}$ \\
\hline Urban Lower & $\begin{array}{l}-0.172 * * * * \\
-(17047)\end{array}$ & $\begin{array}{l}-0.415^{* * *} \\
(0.64)\end{array}$ & $\begin{array}{l}-0.179 * * * * \\
-0.0405)\end{array}$ & $-0.125^{* *}$ & $-0.399^{*}$ & $\begin{array}{l}-0.336 \\
(0.510)\end{array}$ & 0.471 & $\begin{array}{l}0.489 \\
0.607)\end{array}$ \\
\hline Urban Upper & $\begin{array}{c}-0.147 * * * * \\
(0.0451)\end{array}$ & $\begin{array}{l}-0.248^{*} \\
(0.146)\end{array}$ & $\begin{array}{c}-0.115 * *) \\
(0.0390)\end{array}$ & $\begin{array}{c}-0.187 * * * \\
(0.0641)\end{array}$ & $\begin{array}{l}-0.286 \\
(0.224)\end{array}$ & $\begin{array}{l}-0.259 \\
(0.464)\end{array}$ & $\begin{array}{l}-0.0974 \\
(0.549)\end{array}$ & $\begin{array}{l}0.0448 \\
(0.551)\end{array}$ \\
\hline Rural Lower & $\begin{array}{l}-0.158 * * * * \\
-0.0506\end{array}$ & $-0.508^{* * * *}$ & $\begin{array}{c}-0.250 * * * * \\
-0.034)\end{array}$ & $\begin{array}{l}-0.276 * * * \\
0.066\end{array}$ & $\begin{array}{l}-0.320 \\
-0.377\end{array}$ & $\begin{array}{l}-0.254 \\
-0.520)\end{array}$ & 0.588 & $\begin{array}{l}0.629 \\
0.618\end{array}$ \\
\hline Rural Upper & $\begin{array}{l}-0.141 * * \\
(0.0631)\end{array}$ & $\begin{array}{c}-0.721^{* * * *} \\
(0.216)\end{array}$ & $\begin{array}{c}-0.163^{* * * *} \\
(0.0439)\end{array}$ & $\begin{array}{l}-0.179 * * \\
(0.0763)\end{array}$ & $\begin{array}{l}-0.0183 \\
(0.157)\end{array}$ & $\begin{array}{l}0.00827 \\
(0.422)\end{array}$ & $\begin{array}{l}-0.162 \\
(0.483)\end{array}$ & $\begin{array}{l}0.00696 \\
(0.488)\end{array}$ \\
\hline Year & & & & & & & & \\
\hline 2006 & $\begin{array}{l}0.202 * * * \\
(0.0320)\end{array}$ & $\begin{array}{c}0.159 \\
(0.113)\end{array}$ & $\begin{array}{l}0.276 * * * \\
(0.0273)\end{array}$ & $\begin{array}{l}0.223 * * * \\
(0.0537)\end{array}$ & $\begin{array}{c}0.519 * * * \\
(0.121)\end{array}$ & $\begin{array}{c}0.487 * * * \\
(0.108)\end{array}$ & $\begin{array}{l}0.421 * * * \\
(0.0867)\end{array}$ & $\begin{array}{l}0.345 * * * \\
(0.0936)\end{array}$ \\
\hline 2012 & $0.220 * * *$ & $0.288^{* * *}$ & $0.329^{* * * *}$ & $0.178^{* * * *}$ & $0.781^{* * * *}$ & $0.738^{* * * *}$ & $0.561 * * *$ & $0.446 * * *$ \\
\hline Constant & $\begin{array}{c}(0.0332) \\
-0.274 \\
(0.324)\end{array}$ & $\begin{array}{c}(0.122) \\
-0.401 \\
(0.433)\end{array}$ & $\begin{array}{c}(0.0307) \\
-0.596^{* *} \\
(0.289)\end{array}$ & $\begin{array}{c}(0.0598) \\
-0.0576 \\
(0.241)\end{array}$ & $\begin{array}{c}(0.228) \\
0.489 \\
(0.682)\end{array}$ & $\begin{array}{c}(0.193) \\
0.133 \\
(0.729)\end{array}$ & $\begin{array}{l}(0.157) \\
0.0742 \\
(0.599)\end{array}$ & $\begin{array}{l}(0.165) \\
-0.774 \\
(0.611)\end{array}$ \\
\hline Lambda & $\begin{array}{l}-0.0774 \\
(0.152)\end{array}$ & $\begin{array}{l}0.00590 \\
(0.145)\end{array}$ & $\begin{array}{c}0.0422 \\
(0.0938)\end{array}$ & $\begin{array}{l}-0.0904 \\
(0.116)\end{array}$ & $\begin{array}{c}-0.126 \\
(0.0975)\end{array}$ & $\begin{array}{l}-0.0304 \\
(0.0405)\end{array}$ & $\begin{array}{c}-0.137 * * * \\
(0.0516)\end{array}$ & $\begin{array}{l}-0.0566 \\
(0.0433)\end{array}$ \\
\hline Observations & 2,697 & 2,697 & 6,131 & 6,131 & 2,697 & 2,697 & 6,131 & 6,131 \\
\hline Uncensored Obs. & 2421 & 276 & 4289 & 1842 & 2421 & 276 & 4289 & 1842 \\
\hline F-Test & 78.75 & 79.55 & 126.06 & 125.72 & 39.80 & 30.55 & 47.02 & 46.56 \\
\hline rho & -0.135 & 0.010 & 0.066 & -0.131 & -0.495 & 0.669 & -0.386 & 0.561 \\
\hline sigma & 0.574 & 0.577 & 0.636 & 0.691 & 0.586 & 1.428 & 1.285 & 1.970 \\
\hline
\end{tabular}

Sources: Authors' computations using ELMPS data, 1998, 2006, 2012.

Notes:1) $* * *, * *$ and $*$ indicate significance at 1,5 and 10 percent levels respectively.

2) Robust standard errors are in parenthesis. 
TABLE 4: Semi-Parametric Least Squares (SLS) Estimates of Employment Sector Choice by Gender, Egypt 1998-2012

\begin{tabular}{|c|c|c|c|c|}
\hline \multirow[b]{2}{*}{ VARIABLES } & \multicolumn{2}{|c|}{$\begin{array}{c}\text { Female } \\
\text { Wage Earner }\end{array}$} & \multicolumn{2}{|c|}{$\begin{array}{c}\text { Male } \\
\text { Wage Earner } \\
\end{array}$} \\
\hline & $\begin{array}{l}\text { (SLS) } \\
\text { Public }\end{array}$ & $\begin{array}{c}\text { (SLS) } \\
\text { Private }\end{array}$ & $\begin{array}{l}\text { SLS) } \\
\text { Public }\end{array}$ & $\begin{array}{c}\text { (SLS) } \\
\text { Private }\end{array}$ \\
\hline Other_public & $\begin{array}{c}0.113 \\
(0.0913)\end{array}$ & $\begin{array}{c}0.192 * * * \\
(0.0263)\end{array}$ & $\begin{array}{l}0.0959 * * * \\
(0.0176)\end{array}$ & $\begin{array}{c}-1.320 * * * \\
(0.196)\end{array}$ \\
\hline Other_private & $\begin{array}{c}-0.414 * * * \\
(0.0919)\end{array}$ & $\begin{array}{c}-0.0124 * * * \\
(0.00311)\end{array}$ & $\begin{array}{l}0.0116^{* * *} \\
(0.00183)\end{array}$ & $\begin{array}{c}0.115 * * * \\
(0.0156)\end{array}$ \\
\hline Age & $\begin{array}{c}0.0235 \\
(0.0297)\end{array}$ & $\begin{array}{c}0.00708 \\
(0.00868)\end{array}$ & $\begin{array}{l}0.0217 * * * \\
(0.00432)\end{array}$ & $\begin{array}{c}0.181 * * * \\
(0.0387)\end{array}$ \\
\hline Age Squared & $\begin{array}{l}-0.000156 \\
(0.0394)\end{array}$ & $\begin{array}{l}-0.000258 * * \\
(0.0115)\end{array}$ & $\begin{array}{c}-0.000131 * * * \\
(0.00449)\end{array}$ & $\begin{array}{c}-0.000856^{*} \\
(0.0442)\end{array}$ \\
\hline Married & $\begin{array}{l}1.338 * * * \\
(0.0837)\end{array}$ & $\begin{array}{c}-0.143 * * * \\
(0.0279)\end{array}$ & $\begin{array}{l}-0.0226^{*} \\
(0.0122)\end{array}$ & $\begin{array}{l}-0.187 \\
(0.123)\end{array}$ \\
\hline Children & $\begin{array}{l}-0.0164 \\
(0.0943)\end{array}$ & $\begin{array}{c}-0.0862 * * * \\
(0.0235)\end{array}$ & $\begin{array}{c}0.0642 * * * \\
(0.0120)\end{array}$ & $\begin{array}{c}0.646^{* * * *} \\
(0.112)\end{array}$ \\
\hline $\begin{array}{l}\text { Observations } \\
\text { Root MSE }\end{array}$ & $\begin{array}{l}2,699 \\
0.277\end{array}$ & $\begin{array}{l}2,699 \\
0.266\end{array}$ & $\begin{array}{l}6,134 \\
0.408\end{array}$ & $\begin{array}{l}6,134 \\
0.408\end{array}$ \\
\hline
\end{tabular}

Sources: Authors' computations using ELMPS data, 1998, 2006, 2012.

Notes:1) $* * *, * *$ and $*$ indicate significance at 1,5 and 10 percent levels respectively.

2) We also included the sector of work, regions and year dummies. But, the estimates did not convergence in this case. Therefore, they are excluded. 
TABLE 5: Mincer Earnings Equations with Sample Selection Correction, Quantile Regression, Female Sample, Egypt, 1998-2012

\begin{tabular}{|c|c|c|c|c|c|c|c|c|c|c|}
\hline \multirow[b]{3}{*}{ VARIABLES } & \multicolumn{5}{|c|}{ Public } & \multicolumn{5}{|c|}{ Private } \\
\hline & (1) & (2) & (3) & (4) & (5) & (1) & (2) & (3) & (4) & (5) \\
\hline & $\mathrm{q} 10$ & $\mathrm{q} 25$ & $\mathrm{q} 50$ & q75 & $\mathrm{q} 90$ & $\mathrm{q} 10$ & $\mathrm{q} 25$ & $\mathrm{q} 50$ & q75 & $\mathrm{q} 90$ \\
\hline Age & $\begin{array}{c}0.0515^{* * *} \\
(0.0128)\end{array}$ & $\begin{array}{c}0.0554 * * * \\
(0.0118)\end{array}$ & $\begin{array}{c}0.0470^{* * *} * \\
(0.0089)\end{array}$ & $\begin{array}{c}0.0399 * * * \\
(0.0098)\end{array}$ & $\begin{array}{c}0.0150 \\
(0.0178)\end{array}$ & $\begin{array}{c}0.0515^{* * * *} \\
(0.0102)\end{array}$ & $\begin{array}{c}0.0561 \text { *** } \\
(0.0105)\end{array}$ & $\begin{array}{c}0.0484 * * * \\
(0.0085)\end{array}$ & $\begin{array}{c}0.0422^{* * *} * \\
(0.0108)\end{array}$ & $\begin{array}{c}0.0202 \\
(0.0191)\end{array}$ \\
\hline Age Squared & $\begin{array}{l}-0.0002 \\
(0.0002)\end{array}$ & $\begin{array}{c}-0.0003 * * \\
(0.0001)\end{array}$ & $\begin{array}{l}-0.0002 * \\
(0.0001)\end{array}$ & $\begin{array}{l}-0.0001 \\
(0.0001)\end{array}$ & $\begin{array}{c}0.0001 \\
(0.0002)\end{array}$ & $\begin{array}{l}-0.0002 \\
(0.0001)\end{array}$ & $\begin{array}{c}-0.0003^{* *} * \\
(0.0001)\end{array}$ & $\begin{array}{c}-0.0002 * * \\
(0.0001)\end{array}$ & $\begin{array}{c}-0.0002 \\
(0.0001)\end{array}$ & $\begin{array}{c}0.0001 \\
(0.0002)\end{array}$ \\
\hline Year of Schooling & $\begin{array}{c}0.0807 * * * \\
(0.0053)\end{array}$ & $\begin{array}{c}0.0807 * * * \\
(0.0055)\end{array}$ & $\begin{array}{c}0.0714 * * * \\
(0.0041)\end{array}$ & $\begin{array}{c}0.0674 * * * \\
(0.0052)\end{array}$ & $\begin{array}{c}0.0630 * * * \\
(0.0101)\end{array}$ & $\begin{array}{c}0.0804 * * * * \\
(0.0056)\end{array}$ & $\begin{array}{c}0.0820 * * * \\
(0.0063)\end{array}$ & $\begin{array}{c}0.0711 * * * \\
(0.0041)\end{array}$ & $\begin{array}{c}0.0671 * * * \\
(0.0051)\end{array}$ & $\begin{array}{c}0.0643 * * * \\
(0.0110)\end{array}$ \\
\hline Household size & $\begin{array}{c}0.0111 \\
(0.0103)\end{array}$ & $\begin{array}{c}0.0014 \\
(0.0084)\end{array}$ & $\begin{array}{c}0.0041 \\
(0.0057)\end{array}$ & $\begin{array}{l}-0.0051 \\
(0.0100)\end{array}$ & $\begin{array}{l}-0.0160 \\
(0.0124)\end{array}$ & $\begin{array}{c}0.0115 \\
(0.0103)\end{array}$ & $\begin{array}{c}0.0036 \\
(0.0080)\end{array}$ & $\begin{array}{c}0.0057 \\
(0.0061)\end{array}$ & $\begin{array}{c}-0.0076 \\
(0.0105)\end{array}$ & $\begin{array}{c}-0.0163 \\
(0.0130)\end{array}$ \\
\hline Sector & & & & & & & & & & \\
\hline Construction & $\begin{array}{l}-0.7165 \\
(0.6244)\end{array}$ & $\begin{array}{c}0.2764 \\
(0.4351)\end{array}$ & $\begin{array}{c}0.3886 \\
(0.4301)\end{array}$ & $\begin{array}{c}0.3592 \\
(0.4200)\end{array}$ & $\begin{array}{l}0.7679^{*} \\
(0.4124)\end{array}$ & $\begin{array}{l}-0.5698 \\
(0.5818)\end{array}$ & $\begin{array}{c}0.2476 \\
(0.4648)\end{array}$ & $\begin{array}{c}0.3495 \\
(0.3788)\end{array}$ & $\begin{array}{c}0.3135 \\
(0.5177)\end{array}$ & $\begin{array}{l}0.7340^{*} \\
(0.4349)\end{array}$ \\
\hline Trade & $\begin{array}{c}-0.3199 \\
(0.1949)\end{array}$ & $\begin{array}{l}-0.1751 \\
(0.1933)\end{array}$ & $\begin{array}{c}-0.0006 \\
(0.1234)\end{array}$ & $\begin{array}{l}-0.1009 \\
(0.1294)\end{array}$ & $\begin{array}{l}-0.2753 \\
(0.1692)\end{array}$ & $\begin{array}{c}-0.3053 \\
(0.2349)\end{array}$ & $\begin{array}{c}-0.2296 \\
(0.1820)\end{array}$ & $\begin{array}{l}-0.0390 \\
(0.1189)\end{array}$ & $\begin{array}{c}-0.1420 \\
(0.1415)\end{array}$ & $\begin{array}{l}-0.2912 \\
(0.1826)\end{array}$ \\
\hline Transportation & $\begin{array}{l}-0.4541 \\
(0.3087)\end{array}$ & $\begin{array}{l}-0.0655 \\
(0.1194)\end{array}$ & $\begin{array}{c}-0.0999 \\
(0.1021)\end{array}$ & $\begin{array}{l}-0.1776 \\
(0.1657)\end{array}$ & $\begin{array}{l}-0.1785 \\
(0.2890)\end{array}$ & $\begin{array}{l}-0.3235 \\
(0.3237)\end{array}$ & $\begin{array}{l}-0.0274 \\
(0.1102)\end{array}$ & $\begin{array}{l}-0.0699 \\
(0.0908)\end{array}$ & $\begin{array}{l}-0.1465 \\
(0.1629)\end{array}$ & $\begin{array}{l}-0.2051 \\
(0.2582)\end{array}$ \\
\hline Finance \& Services & $\begin{array}{c}-0.3312 * * * \\
(0.1133)\end{array}$ & $\begin{array}{c}-0.2232 * * * \\
(0.0725)\end{array}$ & $\begin{array}{c}-0.2088 * * * \\
(0.0707)\end{array}$ & $\begin{array}{c}-0.3051 * * * \\
(0.0530)\end{array}$ & $\begin{array}{c}-0.2711 * * \\
(0.1276)\end{array}$ & $\begin{array}{c}-0.1968 * * \\
(0.0952)\end{array}$ & $\begin{array}{c}-0.2014 * * * * \\
(0.0780)\end{array}$ & $\begin{array}{c}-0.1518 * * \\
(0.0654)\end{array}$ & $\begin{array}{c}-0.2776 * * * \\
(0.0621)\end{array}$ & $\begin{array}{c}-0.2852 * * \\
(0.1229)\end{array}$ \\
\hline Region & & & & & & & & & & \\
\hline Alexandria, Sz C. & $\begin{array}{l}-0.0904 \\
(0.0627)\end{array}$ & $\begin{array}{c}-0.1059 * * \\
(0.0429)\end{array}$ & $\begin{array}{c}-0.1255^{* * * *} \\
(0.0314)\end{array}$ & $\begin{array}{c}-0.1032 * * \\
(0.0472)\end{array}$ & $\begin{array}{c}-0.2368 * * * \\
(0.0786)\end{array}$ & $\begin{array}{l}-0.0546 \\
(0.0637)\end{array}$ & $\begin{array}{c}-0.0866^{*} \\
(0.0463)\end{array}$ & $\begin{array}{c}-0.1213 * * * \\
(0.0394)\end{array}$ & $\begin{array}{c}-0.1142 * * \\
(0.0554)\end{array}$ & $\begin{array}{c}-0.2333 * * * \\
(0.0864)\end{array}$ \\
\hline Urban Lower & $\begin{array}{l}-0.1195^{*} \\
(0.0636)\end{array}$ & $\begin{array}{c}-0.1265 * * * * \\
(0.0392)\end{array}$ & $\begin{array}{c}-0.1690 * * * * \\
(0.0352)\end{array}$ & $\begin{array}{c}-0.1950 * * * \\
(0.0493)\end{array}$ & $\begin{array}{c}-0.3461 * * * * \\
(0.0870)\end{array}$ & $\begin{array}{l}-0.0828 \\
(0.0657)\end{array}$ & $\begin{array}{c}-0.1027 * * \\
(0.0455)\end{array}$ & $\begin{array}{c}-0.1600 \text { **** } \\
(0.0377)\end{array}$ & $\begin{array}{c}-0.1928 * * * * \\
(0.0447)\end{array}$ & $\begin{array}{c}-0.3312 * * * * \\
(0.0941)\end{array}$ \\
\hline Urban Upper & $\begin{array}{c}-0.1141^{*} \\
(0.0627)\end{array}$ & $\begin{array}{c}-0.1339 * * * * \\
(0.0400)\end{array}$ & $\begin{array}{c}-0.1384 * * * * \\
(0.0325)\end{array}$ & $\begin{array}{c}-0.1261 * * \\
(0.0538)\end{array}$ & $\begin{array}{c}-0.2334 * * * * \\
(0.0760)\end{array}$ & $\begin{array}{l}-0.0788 \\
(0.0647)\end{array}$ & $\begin{array}{c}-0.1219^{* *} \\
(0.0485)\end{array}$ & $\begin{array}{c}-0.1311 \text { *** } \\
(0.0399)\end{array}$ & $\begin{array}{c}-0.1253^{* *} \\
(0.0524)\end{array}$ & $\begin{array}{c}-0.2293 * * * * \\
(0.0847)\end{array}$ \\
\hline Rural Lower & $\begin{array}{c}-0.1337^{*} \\
(0.0703)\end{array}$ & $\begin{array}{c}-0.1397 * * * * \\
(0.0514)\end{array}$ & $\begin{array}{c}-0.1776^{* * * *} \\
(0.0364)\end{array}$ & $\begin{array}{c}-0.1886^{* * * *} \\
(0.0526)\end{array}$ & $\begin{array}{c}-0.3116^{* * * *} \\
(0.0812)\end{array}$ & $\begin{array}{l}-0.0953 \\
(0.0723)\end{array}$ & $\begin{array}{c}-0.1054 * * \\
(0.0527)\end{array}$ & $\begin{array}{c}-0.1641 \text { **** } \\
(0.0401)\end{array}$ & $\begin{array}{c}-0.1930 \text { **** } \\
(0.0500)\end{array}$ & $\begin{array}{c}-0.3167 * * * * \\
(0.0900)\end{array}$ \\
\hline Rural Upper & $\begin{array}{c}-0.3011 * * \\
(0.1370)\end{array}$ & $\begin{array}{c}-0.2124 * * * \\
(0.0739)\end{array}$ & $\begin{array}{c}-0.1462 * * * \\
(0.0514)\end{array}$ & $\begin{array}{c}-0.1646 * * \\
(0.0730)\end{array}$ & $\begin{array}{c}-0.1262 \\
(0.1775)\end{array}$ & $\begin{array}{c}-0.2667 * * \\
(0.1227)\end{array}$ & $\begin{array}{c}-0.1908 * * \\
(0.0753)\end{array}$ & $\begin{array}{c}-0.1248^{* *} \\
(0.0513)\end{array}$ & $\begin{array}{c}-0.1578^{* *} \\
(0.0752)\end{array}$ & $\begin{array}{l}-0.1180 \\
(0.1611)\end{array}$ \\
\hline $\begin{array}{l}\text { Year } \\
\\
2006\end{array}$ & $\begin{array}{c}0.1989 * * * \\
(0.0383)\end{array}$ & $\begin{array}{c}0.1981 * * * \\
(0.0320)\end{array}$ & $\begin{array}{c}0.1505 * * * \\
(0.0306)\end{array}$ & $\begin{array}{c}0.1476 * * * \\
(0.0315)\end{array}$ & $\begin{array}{c}0.2302 * * * \\
(0.0522)\end{array}$ & $\begin{array}{c}0.2047 * * * \\
(0.0476)\end{array}$ & $\begin{array}{c}0.2023 * * * \\
(0.0373)\end{array}$ & $\begin{array}{c}0.1415 * * * \\
(0.0337)\end{array}$ & $\begin{array}{c}0.1491 * * * \\
(0.0319)\end{array}$ & $\begin{array}{c}0.2239 * * * \\
(0.0569)\end{array}$ \\
\hline 2012 & $\begin{array}{c}0.0467 \\
(0.0520)\end{array}$ & $\begin{array}{c}0.2015 * * * \\
(0.0426)\end{array}$ & $\begin{array}{c}0.2833 * * * \\
(0.0354)\end{array}$ & $\begin{array}{c}0.3021 * * * \\
(0.0341)\end{array}$ & $\begin{array}{c}0.3404 * * * \\
(0.0489)\end{array}$ & $\begin{array}{c}0.0561 \\
(0.0513)\end{array}$ & $\begin{array}{c}0.1822 * * * * \\
(0.0489)\end{array}$ & $\begin{array}{c}0.2796 * * * \\
(0.0334)\end{array}$ & $\begin{array}{c}0.2951 * * * \\
(0.0353)\end{array}$ & $\begin{array}{c}0.3391 * * * \\
(0.0508)\end{array}$ \\
\hline Constant & $\begin{array}{c}-1.6052 * * * \\
(0.3082)\end{array}$ & $\begin{array}{c}-1.3684 * * * \\
(0.2461)\end{array}$ & $\begin{array}{c}-0.7519 * * * * \\
(0.1683)\end{array}$ & $\begin{array}{l}-0.1565 \\
(0.2074)\end{array}$ & $\begin{array}{c}0.8328 * * \\
(0.3496)\end{array}$ & $\begin{array}{c}-1.7939 * * * * \\
(0.2716)\end{array}$ & $\begin{array}{c}-1.4898 * * * * \\
(0.2208)\end{array}$ & $\begin{array}{c}-0.8763 * * * * \\
(0.1732)\end{array}$ & $\begin{array}{l}-0.2088 \\
(0.2275)\end{array}$ & $\begin{array}{l}0.7055^{* *} \\
(0.3583)\end{array}$ \\
\hline Lambda & $\begin{array}{l}0.1714 * \\
(0.1000)\end{array}$ & $\begin{array}{c}0.1636 * * * \\
(0.0595)\end{array}$ & $\begin{array}{c}0.1551 \\
(0.4680)\end{array}$ & $\begin{array}{c}0.0686 \\
(0.0513)\end{array}$ & $\begin{array}{c}0.0510 \\
(0.0944)\end{array}$ & $\begin{array}{c}0.0082 \\
(0.0410)\end{array}$ & $\begin{array}{c}0.0367 \\
(0.0270)\end{array}$ & $\begin{array}{c}0.0236 \\
(0.0228)\end{array}$ & $\begin{array}{c}-0.0052 \\
(0.0267)\end{array}$ & $\begin{array}{c}0.0118 \\
(0.0446)\end{array}$ \\
\hline Observations & 2,697 & 2,697 & 2,697 & 2,697 & 2,697 & 2,697 & 2,697 & 2,697 & 2,697 & 2,697 \\
\hline
\end{tabular}

Sources: Authors' computations using ELMPS data, 1998, 2006, 2012.

Notes: 1) ***,** and * indicate significance at 1,5 and 10 percent levels respectively.

2) Bootstrap standard errors are in parenthesis, 100 replications. 
TABLE 6: Mincer Earnings Equations with Sample Selection Correction, Quantile Regression, Male Sample, Egypt, $1998-2012$

\begin{tabular}{|c|c|c|c|c|c|c|c|c|c|c|}
\hline \multirow{2}{*}{ VARIABLES } & \multicolumn{5}{|c|}{ Public } & \multicolumn{5}{|c|}{ Private } \\
\hline & $\begin{array}{l}\text { (1) } \\
\text { g10 }\end{array}$ & $\begin{array}{l}(2) \\
q 25\end{array}$ & $\begin{array}{l}(3) \\
\text { q50 }\end{array}$ & $\begin{array}{l}\text { (4) } \\
\text { g75 }\end{array}$ & $\begin{array}{l}(5) \\
\text { g90 }\end{array}$ & $\begin{array}{l}\text { (1) } \\
\text { g10 }\end{array}$ & $\begin{array}{l}(2) \\
\text { g25 }\end{array}$ & $\begin{array}{l}(3) \\
\text { q50 }\end{array}$ & $\begin{array}{l}\text { (4) } \\
\text { g75 }\end{array}$ & $\begin{array}{l}(5) \\
\text { g90 }\end{array}$ \\
\hline Age & $\begin{array}{c}0.0367 * * * \\
(0.0092)\end{array}$ & $\begin{array}{c}0.0275 * * * \\
(0.0077)\end{array}$ & $\begin{array}{c}0.0262 * * * * \\
(0.0064)\end{array}$ & $\begin{array}{c}0.0154 * * \\
(0.0073)\end{array}$ & $\begin{array}{c}0.0322 * * \\
(0.0135)\end{array}$ & $\begin{array}{c}0.0357 * * * \\
(0.0085)\end{array}$ & $\begin{array}{c}0.0274 * * * \\
(0.0066)\end{array}$ & $\begin{array}{c}0.0266 * * * \\
(0.0071)\end{array}$ & $\begin{array}{c}0.0169 * * \\
(0.0075)\end{array}$ & $\begin{array}{c}0.0314 * * \\
(0.0127)\end{array}$ \\
\hline Age Squared & $\begin{array}{l}-0.0002 \\
(0.0001)\end{array}$ & $\begin{array}{l}-0.0000 \\
(0.0001)\end{array}$ & $\begin{array}{l}-0.0000 \\
(0.0001)\end{array}$ & $\begin{array}{c}0.0001 \\
(0.0001)\end{array}$ & $\begin{array}{l}-0.0002 \\
(0.0002)\end{array}$ & $\begin{array}{l}-0.0002 \\
(0.0001)\end{array}$ & $\begin{array}{l}-0.0000 \\
(0.0001)\end{array}$ & $\begin{array}{l}-0.0000 \\
(0.0001)\end{array}$ & $\begin{array}{c}0.0001 \\
(0.0001)\end{array}$ & $\begin{array}{l}-0.0001 \\
(0.0002)\end{array}$ \\
\hline Year of Schooling & $\begin{array}{c}0.0639 * * * * \\
(0.0030)\end{array}$ & $\begin{array}{c}0.0616^{* * * *} \\
(0.0024)\end{array}$ & $\begin{array}{c}0.0588 * * * * \\
(0.0019)\end{array}$ & $\begin{array}{c}0.0563 * * * \\
(0.0019)\end{array}$ & $\begin{array}{c}0.0592 * * * \\
(0.0036)\end{array}$ & $\begin{array}{c}0.0640 * * * \\
(0.0033)\end{array}$ & $\begin{array}{c}0.0618 * * * \\
(0.0023)\end{array}$ & $\begin{array}{c}0.0587 * * * \\
(0.0019)\end{array}$ & $\begin{array}{c}0.0570 * * * * \\
(0.0020)\end{array}$ & $\begin{array}{c}0.0599 * * * \\
(0.0045)\end{array}$ \\
\hline Household size & $\begin{array}{l}-0.0062 \\
(0.0070)\end{array}$ & $\begin{array}{c}0.0002 \\
(0.0054)\end{array}$ & $\begin{array}{c}0.0026 \\
(0.0031)\end{array}$ & $\begin{array}{l}-0.0012 \\
(0.0042)\end{array}$ & $\begin{array}{c}0.0018 \\
(0.0080)\end{array}$ & $\begin{array}{l}-0.0061 \\
(0.0066)\end{array}$ & $\begin{array}{c}0.0007 \\
(0.0057)\end{array}$ & $\begin{array}{c}0.0033 \\
(0.0032)\end{array}$ & $\begin{array}{l}-0.0012 \\
(0.0041)\end{array}$ & $\begin{array}{c}0.0022 \\
(0.0090)\end{array}$ \\
\hline Sector & & & & & & & & & & \\
\hline Construction & $\begin{array}{c}0.1260 \\
(0.0776)\end{array}$ & $\begin{array}{c}0.1213 * * \\
(0.0577)\end{array}$ & $\begin{array}{c}0.1997 * * * \\
(0.0662)\end{array}$ & $\begin{array}{c}0.2291 * * * \\
(0.0549)\end{array}$ & $\begin{array}{l}0.3298^{*} \\
(0.1748)\end{array}$ & $\begin{array}{c}0.1257 \\
(0.1006)\end{array}$ & $\begin{array}{c}0.1182 * * \\
(0.0538)\end{array}$ & $\begin{array}{c}0.2031 * * * * \\
(0.0722)\end{array}$ & $\begin{array}{c}0.2373 * * * \\
(0.0678)\end{array}$ & $\begin{array}{c}0.3420 * * \\
(0.1652)\end{array}$ \\
\hline Trade & $\begin{array}{c}-0.2491 \text { **** } \\
(0.0660)\end{array}$ & $\begin{array}{c}-0.2262 * * * * \\
(0.0547)\end{array}$ & $\begin{array}{c}-0.1564 * * * * \\
(0.0462)\end{array}$ & $\begin{array}{c}-0.1280^{* *} \\
(0.0536)\end{array}$ & $\begin{array}{c}-0.1534 * \\
(0.0850)\end{array}$ & $\begin{array}{c}-0.2439 * * * \\
(0.0642)\end{array}$ & $\begin{array}{c}-0.2310 * * * * \\
(0.0553)\end{array}$ & $\begin{array}{c}-0.1536 * * * * \\
(0.0496)\end{array}$ & $\begin{array}{c}-0.1323^{* * *} \\
(0.0533)\end{array}$ & $\begin{array}{c}-0.1433^{*} \\
(0.0808)\end{array}$ \\
\hline Transportation & $\begin{array}{c}0.0161 \\
(0.0499)\end{array}$ & $\begin{array}{c}0.1032 * * * \\
(0.0349)\end{array}$ & $\begin{array}{c}0.1270 * * * * \\
(0.0321)\end{array}$ & $\begin{array}{c}0.1712 * * * * \\
(0.0388)\end{array}$ & $\begin{array}{c}0.1497 * * \\
(0.0655)\end{array}$ & $\begin{array}{c}0.0123 \\
(0.0574)\end{array}$ & $\begin{array}{c}0.1061^{* * * *} \\
(0.0367)\end{array}$ & $\begin{array}{c}0.1306 * * * * \\
(0.0318)\end{array}$ & $\begin{array}{c}0.1806 * * * * \\
(0.0415)\end{array}$ & $\begin{array}{c}0.1552 * * \\
(0.0736)\end{array}$ \\
\hline Finance \& Services & $\begin{array}{c}-0.1797 * * * \\
(0.0526)\end{array}$ & $\begin{array}{l}-0.0687 * \\
(0.0376)\end{array}$ & $\begin{array}{c}-0.0765^{* * *} * \\
(0.0282)\end{array}$ & $\begin{array}{l}-0.0414 \\
(0.0335)\end{array}$ & $\begin{array}{l}-0.0745 \\
(0.0517)\end{array}$ & $\begin{array}{c}-0.1872 * * * \\
(0.0465)\end{array}$ & $\begin{array}{c}-0.0705^{* *} \\
(0.0346)\end{array}$ & $\begin{array}{c}-0.0723 * * * * \\
(0.0267)\end{array}$ & $\begin{array}{l}-0.0408 \\
(0.0323)\end{array}$ & $\begin{array}{l}-0.0703 \\
(0.0602)\end{array}$ \\
\hline Region & & & & & & & & & & \\
\hline Alexandria, Sz C. & $\begin{array}{c}-0.0008 \\
(0.0470)\end{array}$ & $\begin{array}{l}-0.0290 \\
(0.0422)\end{array}$ & $\begin{array}{c}-0.0383 \\
(0.0318)\end{array}$ & $\begin{array}{l}-0.0430 \\
(0.0346)\end{array}$ & $\begin{array}{l}-0.1072 \\
(0.0742)\end{array}$ & $\begin{array}{c}-0.0023 \\
(0.0358)\end{array}$ & $\begin{array}{c}-0.0272 \\
(0.0343)\end{array}$ & $\begin{array}{l}-0.0384 \\
(0.0346)\end{array}$ & $\begin{array}{c}-0.0332 \\
(0.0410)\end{array}$ & $\begin{array}{c}-0.1107 \\
(0.0713)\end{array}$ \\
\hline Urban Lower & $\begin{array}{c}-0.0694^{*} \\
(0.0366)\end{array}$ & $\begin{array}{c}-0.1255 * * * * \\
(0.0321)\end{array}$ & $\begin{array}{c}-0.1687 * * * * \\
(0.0291)\end{array}$ & $\begin{array}{c}-0.2015 * * * \\
(0.0337)\end{array}$ & $\begin{array}{c}-0.2335 * * * \\
(0.0728)\end{array}$ & $\begin{array}{c}-0.0729^{* *} \\
(0.0333)\end{array}$ & $\begin{array}{c}-0.1297 * * * \\
(0.0328)\end{array}$ & $\begin{array}{c}-0.1703 * * * * \\
(0.0255)\end{array}$ & $\begin{array}{c}-0.2047 * * * * \\
(0.0383)\end{array}$ & $\begin{array}{c}-0.2330 * * * \\
(0.0738)\end{array}$ \\
\hline Urban Upper & $\begin{array}{c}-0.0946 * * \\
(0.0481)\end{array}$ & $\begin{array}{c}-0.0730^{* *} \\
(0.0320)\end{array}$ & $\begin{array}{c}-0.1038^{* * *} * \\
(0.0228)\end{array}$ & $\begin{array}{c}-0.1378 * * * \\
(0.0330)\end{array}$ & $\begin{array}{c}-0.2371 * * * \\
(0.0662)\end{array}$ & $\begin{array}{c}-0.0934^{*} \\
(0.0509)\end{array}$ & $\begin{array}{c}-0.0762 * * \\
(0.0358)\end{array}$ & $\begin{array}{c}-0.1084 * * * \\
(0.0263)\end{array}$ & $\begin{array}{c}-0.1307 * * * \\
(0.0359)\end{array}$ & $\begin{array}{c}-0.2361 * * * \\
(0.0691)\end{array}$ \\
\hline Rural Lower & $\begin{array}{c}-0.1575 * * * \\
(0.0387)\end{array}$ & $\begin{array}{c}-0.2127 * * * * \\
(0.0310)\end{array}$ & $\begin{array}{c}-0.2313 * * * * \\
(0.0274)\end{array}$ & $\begin{array}{c}-0.2912 * * * * \\
(0.0344)\end{array}$ & $\begin{array}{c}-0.4146 * * * \\
(0.0642)\end{array}$ & $\begin{array}{c}-0.1589 * * * \\
(0.0383)\end{array}$ & $\begin{array}{c}-0.2139 * * * \\
(0.0290)\end{array}$ & $\begin{array}{c}-0.2356 * * * * \\
(0.0235)\end{array}$ & $\begin{array}{c}-0.2900 * * * * \\
(0.0369)\end{array}$ & $\begin{array}{c}-0.4163^{* * * *} \\
(0.0622)\end{array}$ \\
\hline Rural Upper & $\begin{array}{c}-0.1398^{* * *} \\
(0.0434)\end{array}$ & $\begin{array}{c}-0.1697 * * * \\
(0.0378)\end{array}$ & $\begin{array}{c}-0.1619 * * * \\
(0.0276)\end{array}$ & $\begin{array}{c}-0.1898 * * * \\
(0.0348)\end{array}$ & $\begin{array}{c}-0.2027^{* *} \\
(0.0892)\end{array}$ & $\begin{array}{c}-0.1371^{* * *} \\
(0.0428)\end{array}$ & $\begin{array}{c}-0.1727 * * * \\
(0.0359)\end{array}$ & $\begin{array}{c}-0.1671 * * * \\
(0.0284)\end{array}$ & $\begin{array}{c}-0.1880 * * * \\
(0.0392)\end{array}$ & $\begin{array}{c}-0.1978 * * \\
(0.0976)\end{array}$ \\
\hline $\begin{array}{l}\text { Year } \\
\\
2006\end{array}$ & $\begin{array}{c}0.2248 * * * \\
(0.0313)\end{array}$ & $\begin{array}{c}0.2357 * * * \\
(0.0251)\end{array}$ & $\begin{array}{c}0.2299 * * * \\
(0.0164)\end{array}$ & $\begin{array}{c}0.1979 * * * \\
(0.0229)\end{array}$ & $\begin{array}{c}0.3424 * * * \\
(0.0524)\end{array}$ & $\begin{array}{c}0.2241 * * * * \\
(0.0289)\end{array}$ & $\begin{array}{c}0.2343 * * * * \\
(0.0244)\end{array}$ & $\begin{array}{c}0.2322 * * * \\
(0.0173)\end{array}$ & $\begin{array}{c}0.1958 * * * \\
(0.0265)\end{array}$ & $\begin{array}{c}0.3445^{* * * *} \\
(0.0526)\end{array}$ \\
\hline 2012 & $\begin{array}{c}0.1780^{* * * *} \\
(0.0328)\end{array}$ & $\begin{array}{c}0.2701 * * * \\
(0.0247)\end{array}$ & $\begin{array}{c}0.3146 * * * \\
(0.0187)\end{array}$ & $\begin{array}{c}0.3443 * * * * \\
(0.0228)\end{array}$ & $\begin{array}{c}0.3861 * * * \\
(0.0431)\end{array}$ & $\begin{array}{c}0.1770 * * * \\
(0.0306)\end{array}$ & $\begin{array}{c}0.2689 * * * * \\
(0.0266)\end{array}$ & $\begin{array}{c}0.3165^{* * * *} \\
(0.0180)\end{array}$ & $\begin{array}{c}0.3456 * * * \\
(0.0285)\end{array}$ & $\begin{array}{c}0.3875^{* * * *} \\
(0.0437)\end{array}$ \\
\hline Constant & $\begin{array}{c}-0.9469^{* * *} \\
(0.2015)\end{array}$ & $\begin{array}{c}-0.5739 * * * \\
(0.1665)\end{array}$ & $\begin{array}{l}-0.2275^{*} \\
(0.1288)\end{array}$ & $\begin{array}{c}0.4120 * * * * \\
(0.1499)\end{array}$ & $\begin{array}{l}0.5252 * \\
(0.2783)\end{array}$ & $\begin{array}{c}-0.9418 * * * \\
(0.1936)\end{array}$ & $\begin{array}{c}-0.6004 * * * \\
(0.1462)\end{array}$ & $\begin{array}{c}-0.2778^{*} \\
(0.1481)\end{array}$ & $\begin{array}{l}0.3124 * \\
(0.1606)\end{array}$ & $\begin{array}{l}0.4705^{*} \\
(0.2815)\end{array}$ \\
\hline Lambda & $\begin{array}{l}-0.0486 \\
(0.0330)\end{array}$ & $\begin{array}{l}-0.0795 \\
(0.2192)\end{array}$ & $\begin{array}{c}-0.0947 * \\
(0.0505)\end{array}$ & $\begin{array}{l}-0.1318 \\
(0.2091)\end{array}$ & $\begin{array}{c}-0.1399 * * * \\
(0.0330)\end{array}$ & $\begin{array}{l}-0.0559 \\
(0.0466)\end{array}$ & $\begin{array}{l}-0.1071 \\
(0.3101)\end{array}$ & $\begin{array}{c}-0.1345^{* * * *} \\
(0.0279)\end{array}$ & $\begin{array}{c}-0.1866^{*} \\
(0.1354)\end{array}$ & $\begin{array}{c}-0.1957 * * * * \\
(0.0588)\end{array}$ \\
\hline Observations & 6,131 & 6,131 & 6,131 & 6,131 & 6,131 & 6,131 & 6,131 & 6,131 & 6,131 & 6,131 \\
\hline
\end{tabular}

Sources: Authors' computations using ELMPS data, 1998, 2006, 2012

Notes: 1$) * * *, * *$ and $*$ indicate significance at 1,5 and 10 percent levels respectively.

2) Bootstrap standard errors are in parenthesis, 100 replications. 
TABLE 7: Decomposition of Public-Private Wage Differentials by Gender and Male-Female Wage Differentials by Sector of Work, Egypt, 1998-2012

\begin{tabular}{llllll}
\hline & \multicolumn{2}{c}{$\begin{array}{c}\text { Mean Log Wage Differential } \\
\text { Between Public and Private } \\
\text { Wage Differential }\end{array}$} & & \multicolumn{2}{c}{$\begin{array}{c}\text { Mean Log Wage Differential } \\
\text { Between Male and Female } \\
\text { Workers }\end{array}$} \\
\cline { 2 - 3 } $\begin{array}{l}\text { Total mean differential } \\
\text { Component attributable to: }\end{array}$ & 0.249 & -0.003 & & 0.017 & 0.270 \\
$\quad$ Constant & 0.127 & -0.538 & & -0.102 & 0.035 \\
$\quad$ Endowments & 0.048 & 0.169 & & -0.028 & -0.031 \\
$\quad$ Coefficient & 0.092 & 0.297 & & 0.234 & 0.197 \\
$\quad$ Selection & -0.014 & 0.123 & & 0.086 & -0.256 \\
Total unexplained differential & 0.220 & -0.240 & & 0.132 & 0.233 \\
\hline
\end{tabular}

Sources: Authors' computations using ELMPS data, 1998, 2006, 2012. 
TABLE 8: Summary of Estimation Results: Public-Private Sector Wage Gap by Gender, Egypt, 1998-2012

\begin{tabular}{|c|c|c|c|c|c|c|}
\hline & & & ale & & & \\
\hline & mean & q10 & $\mathrm{q} 25$ & $\mathrm{q} 50$ & q75 & q90 \\
\hline Estimation Method & & & & & & \\
\hline RAW WAGE GAP & & & & & & \\
\hline & $(0.0208)$ & $(0.0279)$ & $(0.0253)$ & $(0.0182)$ & $(0.0225)$ & $(0.0514)$ \\
\hline OLS and QR & & & & & & \\
\hline Public Wage Gap & $-0.136 * * *$ & -0.0582 & $-0.1057 * * *$ & $-0.1362 * * *$ & $-0.1934 * * *$ & $-0.1932 * * *$ \\
\hline & $(0.0262)$ & $(0.0455)$ & $(0.0273)$ & $(0.0303)$ & $(0.0329)$ & $(0.0536)$ \\
\hline FE and FEQR & & & & & & \\
\hline Public Wage Gap & $-0.278 * * *$ & $-0.2639 * * *$ & $-0.2976^{* * *}$ & $-0.2779 * * *$ & $-0.2192 * * *$ & $-0.2707 * * *$ \\
\hline & $(0.0953)$ & $(0.0349)$ & $(0.0157)$ & $(0.0000)$ & $(0.0192)$ & $(0.0296)$ \\
\hline & & & nale & & & \\
\hline & mean & q10 & $\mathrm{q} 25$ & q50 & q75 & q90 \\
\hline Estimation Method & & & & & & \\
\hline RAW WAGE GAP & & & & & & \\
\hline Public Wage Gap & $0.250 * * *$ & $0.3763 * * *$ & $0.3653 * * *$ & $0.2877 * * *$ & $0.1316 * *$ & $0.1643 * *$ \\
\hline OLS and QR & & & & & & \\
\hline Public Wage Gap & $0.109 * *$ & $0.1822 *$ & $0.1539 * * *$ & $0.1352 * * *$ & 0.0727 & 0.0496 \\
\hline & $(0.0493)$ & $(0.1019)$ & $(0.0518)$ & $(0.0501)$ & $(0.0521)$ & $(0.0903)$ \\
\hline $\mathrm{FE}$ & & & & & & \\
\hline Public Wage Gap & -0.135 & - & - & - & - & - \\
\hline & $(0.134)$ & & & & & \\
\hline
\end{tabular}

Sources: Authors' computations using ELMPS data, 1998, 2006, 2012.

Notes: 1$) * * *, * *$ and $*$ indicate significance at 1,5 and 10 percent levels respectively.

2) OLS indicates ordinary least squares estimates. QR indicates quantile regression estimates. FE is fixed effect estimates. FEQR is the fixed effect quantile regression estimates. OLS and FE standard errors are robust and QR and FEQR standard errors are computed by bootstrap method 100 replications.

3) Regression coefficients on the table are based on the regressions reported in Appendix A, Tables A2-A5. 
TABLE 9: Public Sector Wage Gap by Education Levels, Male Sample, Egypt, 1998-2012

\begin{tabular}{|c|c|c|c|c|c|}
\hline & & $\begin{array}{l}\text { Less than } \\
\text { Primary }\end{array}$ & $\begin{array}{l}\text { Less than } \\
\text { Intermediate }\end{array}$ & $\begin{array}{l}\text { Intermediate } \\
\text { and Above }\end{array}$ & $\begin{array}{l}\text { University } \\
\text { and Above }\end{array}$ \\
\hline \multirow[t]{2}{*}{ Male } & FE & -0.148 & 0.0769 & $-0.306 * *$ & $-0.434 * *$ \\
\hline & & $(0.239)$ & $(0.225)$ & $(0.15)$ & $(0.179)$ \\
\hline \multirow[t]{11}{*}{ FEQR } & q10 & -0.1208 & 0.0102 & $-0.3107 * * *$ & $-0.2681 * * *$ \\
\hline & & $(0.0788)$ & $(0.0522)$ & $(0.0475)$ & $(0.0774)$ \\
\hline & q25 & $-0.1482 * * *$ & $0.0540 * * *$ & $-0.3122 * * *$ & $-0.4151 * * *$ \\
\hline & & $(0.0167)$ & $(0.0156)$ & $(0.0185)$ & $(0.0314)$ \\
\hline & q50 & $-0.1482 * * *$ & $0.0656 * * *$ & $-0.3058 * * *$ & $-0.3972 * * *$ \\
\hline & & $(0.000)$ & $(0.000)$ & $(0.000)$ & $(0.000)$ \\
\hline & q75 & $-0.1482 * * *$ & $0.0795 * * *$ & $-0.2648 * * *$ & $-0.3705 * * *$ \\
\hline & & $(0.0192)$ & $(0.0197)$ & $(0.0273)$ & $(0.0268)$ \\
\hline & q90 & $-0.1970 * *$ & $0.1421 * *$ & $-0.2645^{* * *}$ & $-0.4506 * * *$ \\
\hline & & $(0.0985)$ & $(0.0631)$ & $(0.0622)$ & $(0.0646)$ \\
\hline & Observations & 834 & 758 & 2610 & 1929 \\
\hline
\end{tabular}

Source: Authors computations using ELMPS 2008, 2006 and 2012.

Notes: 1) $* * *, * *$ and $*$ indicate significance at 1,5 and 10 percent levels.

2) Each of the regressions includes a constant, Age, Age Squared, Years of Schooling, Dummies for marital status, having children, household size, and dummies for time and dummies for regions. These are not reported for brevity.

3) FE standard errors are robust and FEQR standard errors are computed by bootstrap method 100 replications.

TABLE 10: Summary Results by the Subsamples of Two Time Periods, Age and Education, Male Sample, Egypt, 1998-2012

\begin{tabular}{|c|c|c|c|c|c|c|c|}
\hline & & mean & $\mathrm{q} 10$ & $q 25$ & $q 50$ & q75 & q90 \\
\hline \multicolumn{8}{|l|}{ (1998-2006) } \\
\hline & Public Wage Gap & $\begin{array}{l}-0.508 \\
(0.421)\end{array}$ & $\begin{array}{l}-0.4904 * * * \\
(0.0167)\end{array}$ & $\begin{array}{l}-0.4892^{* * *} \\
(0.000)\end{array}$ & $\begin{array}{l}-0.4892^{* * *} \\
(0.000)\end{array}$ & $\begin{array}{l}-0.4892 * * * \\
(0.000)\end{array}$ & $\begin{array}{l}-0.4782 * \\
(0.0197)\end{array}$ \\
\hline \multirow{2}{*}{$\begin{array}{l}\text { Observations } \\
\text { (2006-2012) }\end{array}$} & & 2777 & 2777 & 2777 & 2777 & 2777 & 2777 \\
\hline & Public Wage Gap & $\begin{array}{l}-0.204 * \\
(0.121)\end{array}$ & $\begin{array}{l}-0.204 * \\
(0.121)\end{array}$ & $\begin{array}{l}-0.2131 * * * \\
(0.0349)\end{array}$ & $\begin{array}{l}-0.2185^{* * * *} \\
(0.0073)\end{array}$ & $\begin{array}{l}-0.2037 * * * \\
(0.000)\end{array}$ & $\begin{array}{l}-0.1903 * \\
(0.0076)\end{array}$ \\
\hline Observations & & 3793 & 3793 & 3793 & 3793 & 3793 & 3793 \\
\hline
\end{tabular}




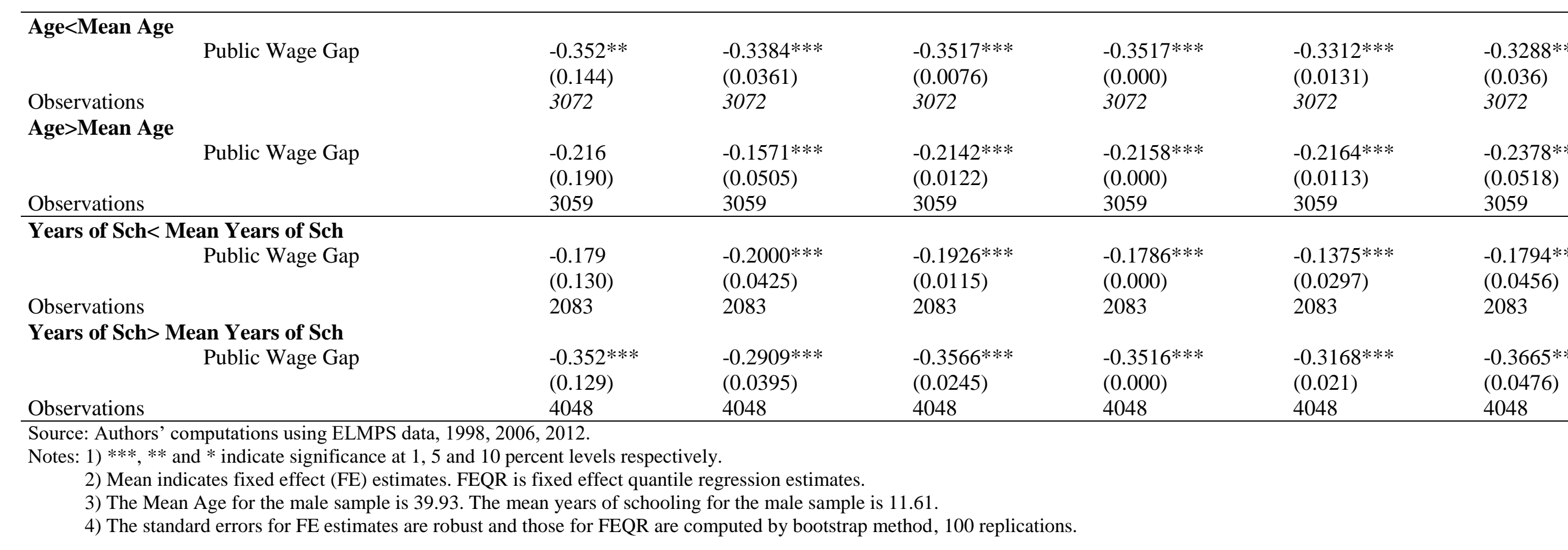


TABLE 11: Average Log Hourly Wage by Gender and Region, Egypt, 1998-2012

\begin{tabular}{lccccccc}
\hline & Egypt & Gr. Cairo & Alx, Sz C. & Urb. Lwr. & Urb. Upp. Rur. Lwr. & Rur. Upp. \\
\hline Pooled Data & & & & & & & \\
$\quad$ All & 1.577 & 1.783 & 1.677 & 1.568 & 1.594 & 1.428 & 1.453 \\
$\quad$ Male & 1.591 & 1.790 & 1.720 & 1.601 & 1.629 & 1.435 & 1.474 \\
$\quad$ Female & 1.547 & 1.769 & 1.599 & 1.511 & 1.531 & 1.407 & 1.328 \\
$\mathbf{1 9 9 8}$ & & & & & & & \\
All & 1.344 & 1.603 & 1.412 & 1.310 & 1.353 & 1.128 & 1.094 \\
Male & 1.340 & 1.571 & 1.481 & 1.307 & 1.375 & 1.144 & 1.088 \\
Female & 1.353 & 1.662 & 1.294 & 1.315 & 1.316 & 1.074 & 1.139 \\
$\mathbf{2 0 0 6}$ & & & & & & & \\
All & 1.612 & 1.839 & 1.732 & 1.622 & 1.656 & 1.411 & 1.458 \\
Male & 1.630 & 1.864 & 1.791 & 1.658 & 1.692 & 1.420 & 1.493 \\
Female & 1.571 & 1.789 & 1.622 & 1.560 & 1.594 & 1.382 & 1.191 \\
$\mathbf{2 0 1 2}$ & & & & & & & \\
All & 1.674 & 1.850 & 1.797 & 1.697 & 1.697 & 1.551 & 1.574 \\
Male & 1.691 & 1.858 & 1.801 & 1.758 & 1.739 & 1.558 & 1.601 \\
Female & 1.638 & 1.832 & 1.789 & 1.598 & 1.619 & 1.532 & 1.454 \\
\hline
\end{tabular}

Source: Authors' computations using ELMPS data, 1998, 2006, 2012.

Notes: Log hourly wage is in Egyptian Pounds real 2012 prices deflated using consumer price index. 
TABLE 12: Public Sector Wage Gap by Region, Male Sample, Egypt, 1998-2012

\begin{tabular}{|c|c|c|c|c|c|c|c|}
\hline & & $\begin{array}{l}\text { Greater } \\
\text { Cairo }\end{array}$ & $\begin{array}{l}\text { Alexandria, } \\
\text { Sz. C }\end{array}$ & $\begin{array}{l}\text { Urban } \\
\text { Lower }\end{array}$ & $\begin{array}{l}\text { Urban } \\
\text { Upper }\end{array}$ & $\begin{array}{l}\text { Rural } \\
\text { Lower }\end{array}$ & $\begin{array}{l}\text { Rural } \\
\text { Upper }\end{array}$ \\
\hline \multirow[t]{2}{*}{ Male } & FE & -0.23 & -0.274 & $-0.468^{*}$ & $-0.245^{*}$ & $-0.433 * * *$ & 0.0522 \\
\hline & & $(0.215)$ & (0.392) & $(0.27)$ & (0.139) & $(0.137)$ & $(0.257)$ \\
\hline \multirow[t]{10}{*}{ FEQR } & q10 & $-0.1172 *$ & $-0.2309 * * *$ & $-0.4103 * * *$ & $-0.1655^{*}$ & $-0.3792 * * *$ & 0.059 \\
\hline & & $(0.0698)$ & $(0.0594)$ & $(0.086)$ & $(0.0949)$ & $(0.0521)$ & 80.0929) \\
\hline & $\mathrm{q} 25$ & $-0.2402 * * *$ & $-0.3003 * * *$ & $-0.5293 * * *$ & $-0.2620 * * *$ & $-0.4546 * * *$ & 0.0348 \\
\hline & & $(0.0267)$ & $(0.0428)$ & $(0.0419)$ & $(0.0302)$ & $(0.0281)$ & $(0.0244)$ \\
\hline & q50 & $-0.2301 * * *$ & $-0.2739 * * *$ & $-0.4683 * * *$ & $-0.2453 * * *$ & $-0.4332 * * *$ & $0.0522 * * *$ \\
\hline & & $(0.000)$ & $(0.000)$ & $(0.000)$ & $(0.000)$ & $(0.000)$ & $(0.000)$ \\
\hline & q75 & $-0.2231 * * *$ & $-0.1903 * * *$ & $-0.4007 * * *$ & $-0.1586 * * *$ & $-0.4077 * * *$ & $0.0565 * *$ \\
\hline & & $(0.0295)$ & (0.0397) & $(0.048)$ & $(0.0314)$ & $(0.0262)$ & $(0.0242)$ \\
\hline & q90 & $-0.2260 * * *$ & $-0.2345 * * *$ & $-0.4787 * * *$ & $-0.2088^{* *}$ & $-0.4677 * * *$ & 0.1315 \\
\hline & & (0.0729) & $(0.0608)$ & $(0.1269)$ & $(0.087)$ & $(0.0612)$ & (0.0899) \\
\hline Observations & & 1026 & 670 & 809 & 1201 & 1531 & 894 \\
\hline
\end{tabular}

Source: Authors computations using ELMPS 2008, 2006 and 2012.

Notes: 1) ***, **and * indicate significance at 1,5 and 10 percent levels.

2) Each of the regressions includes a constant, age, age squared, years of schooling, dummies for marital status, having children, household size and dummies for time. These are not reported for brevity.

3) The standard errors for FE are robust and those of FEQR are computed by bootstrap method, 100 replications. 
APPENDIX-A

TABLE A1: Mincer Earnings Equations, OLS and Fixed Effects, Egypt, 1998-2012

\begin{tabular}{|c|c|c|c|c|}
\hline VARIABLES & $\begin{array}{l}\text { (OLS) } \\
\text { Male }\end{array}$ & $\begin{array}{l}\text { (OLS) } \\
\text { Female }\end{array}$ & $\begin{array}{l}\text { (FE) } \\
\text { Male }\end{array}$ & $\begin{array}{l}\text { (FE) } \\
\text { Female }\end{array}$ \\
\hline Public wage gap & $-0.136^{* * *}$ & $0.109 * *$ & $-0.278 * * *$ & -0.135 \\
\hline & $(0.0262)$ & $(0.0493)$ & $(0.0953)$ & $(0.134)$ \\
\hline Age & $\begin{array}{c}0.0262 * * * \\
(0.00744)\end{array}$ & $\begin{array}{c}0.0324 * * * \\
(0.00873)\end{array}$ & $\begin{array}{c}0.0498 * * * \\
(0.0177)\end{array}$ & $\begin{array}{c}0.0449 * * \\
(0.0205)\end{array}$ \\
\hline Age Squared & $\begin{array}{c}-0.0000611 \\
(0.00895)\end{array}$ & $\begin{array}{c}-0.0000476 \\
(0.0110)\end{array}$ & $\begin{array}{c}-0.000413^{* *} \\
(0.0163)\end{array}$ & $\begin{array}{c}-0.000612 * * * \\
(0.0198)\end{array}$ \\
\hline Year of Schooling & $\begin{array}{l}0.0604 * * * \\
(0.00208)\end{array}$ & $\begin{array}{l}0.0682 * * * \\
(0.00446)\end{array}$ & $\begin{array}{l}0.00259 \\
(0.0119)\end{array}$ & $\begin{array}{l}0.0315^{*} \\
(0.0186)\end{array}$ \\
\hline Married & $\begin{array}{c}0.0928 * * * \\
(0.0304)\end{array}$ & $\begin{array}{c}0.0863 * * * \\
(0.0305)\end{array}$ & $\begin{array}{l}0.121 * * \\
(0.0592)\end{array}$ & $\begin{array}{c}0.0151 \\
(0.0635)\end{array}$ \\
\hline Children & $\begin{array}{c}-0.0687 * * * \\
(0.0226)\end{array}$ & $\begin{array}{l}-0.0188 \\
(0.0293)\end{array}$ & $\begin{array}{l}-0.0142 \\
(0.0406)\end{array}$ & $\begin{array}{l}-0.0459 \\
(0.0496)\end{array}$ \\
\hline Household size & $\begin{array}{c}0.00466 \\
(0.00429)\end{array}$ & $\begin{array}{l}-0.00606 \\
(0.00735)\end{array}$ & $\begin{array}{c}0.0129^{*} \\
(0.00724)\end{array}$ & $\begin{array}{l}0.00208 \\
(0.0141)\end{array}$ \\
\hline Sector & & & & \\
\hline Construction & $\begin{array}{c}0.168 * * * \\
(0.0590)\end{array}$ & $\begin{array}{c}0.291 \\
(0.288)\end{array}$ & $\begin{array}{l}-0.0966 \\
(0.182)\end{array}$ & $\begin{array}{l}0.0341 \\
(0.567)\end{array}$ \\
\hline Trade & $\begin{array}{c}-0.199 * * * \\
(0.0454)\end{array}$ & $\begin{array}{l}-0.179 * \\
(0.102)\end{array}$ & $\begin{array}{c}-0.00424 \\
(0.121)\end{array}$ & $\begin{array}{l}-0.182 \\
(0.205)\end{array}$ \\
\hline Transportation & $\begin{array}{c}0.103 * * * \\
(0.0342)\end{array}$ & $\begin{array}{l}-0.102 \\
(0.112)\end{array}$ & $\begin{array}{l}0.0348 \\
(0.110)\end{array}$ & $\begin{array}{c}0.00686 \\
(0.254)\end{array}$ \\
\hline Finance \& Services & $\begin{array}{c}-0.0835 * * * \\
(0.0290)\end{array}$ & $\begin{array}{c}-0.231 * * * \\
(0.0594)\end{array}$ & $\begin{array}{c}-0.104 \\
(0.0816)\end{array}$ & $\begin{array}{l}-0.170 \\
(0.165)\end{array}$ \\
\hline Region & & & & \\
\hline Alexandria, Sz C. & $\begin{array}{l}-0.0538 \\
(0.0340)\end{array}$ & $\begin{array}{c}-0.114 * * * \\
(0.0382)\end{array}$ & $\begin{array}{c}0.523 * * \\
(0.255)\end{array}$ & $\begin{array}{c}0.134 \\
(0.347)\end{array}$ \\
\hline Urban Lower & $\begin{array}{c}-0.150 * * * \\
(0.0319)\end{array}$ & $\begin{array}{c}-0.202 * * * \\
(0.0354)\end{array}$ & $\begin{array}{c}0.583 * * \\
(0.253)\end{array}$ & $\begin{array}{l}-0.321 \\
(0.266)\end{array}$ \\
\hline Urban Upper & $\begin{array}{c}-0.123 * * * \\
(0.0300)\end{array}$ & $\begin{array}{c}-0.165^{* * * *} \\
(0.0354)\end{array}$ & $\begin{array}{l}0.0370 \\
(0.269)\end{array}$ & $\begin{array}{l}-0.291 \\
(0.248)\end{array}$ \\
\hline Rural Lower & $\begin{array}{c}-0.259 * * * \\
(0.0286)\end{array}$ & $\begin{array}{c}-0.200 * * * \\
(0.0382)\end{array}$ & $\begin{array}{c}0.675 * * \\
(0.278)\end{array}$ & $\begin{array}{l}-0.232 \\
(0.309)\end{array}$ \\
\hline Rural Upper & $\begin{array}{c}-0.168 * * * \\
(0.0337)\end{array}$ & $\begin{array}{c}-0.197 * * * \\
(0.0710)\end{array}$ & $\begin{array}{l}-0.0616 \\
(0.124)\end{array}$ & $\begin{array}{l}-0.0209 \\
(0.183)\end{array}$ \\
\hline Year & & & & \\
\hline 2006 & $\begin{array}{c}0.274 * * * \\
(0.0206)\end{array}$ & $\begin{array}{c}0.198 * * * \\
(0.0268)\end{array}$ & $\begin{array}{c}0.389 * * * \\
(0.0751)\end{array}$ & $\begin{array}{c}0.496 * * * \\
(0.121)\end{array}$ \\
\hline 2012 & $\begin{array}{c}0.286 * * * \\
(0.0215)\end{array}$ & $\begin{array}{c}0.225 * * * \\
(0.0294)\end{array}$ & $\begin{array}{c}0.510 * * * \\
(0.138)\end{array}$ & $\begin{array}{c}0.742 * * * \\
(0.228)\end{array}$ \\
\hline Constant & $\begin{array}{c}-0.0432 \\
(0.141)\end{array}$ & $\begin{array}{c}-0.490 * * * \\
(0.170)\end{array}$ & $\begin{array}{l}-0.270 \\
(0.464)\end{array}$ & $\begin{array}{c}0.321 \\
(0.666)\end{array}$ \\
\hline Observations & 6,131 & 2,697 & 6,131 & 2,697 \\
\hline R-squared & 0.241 & 0.310 & 0.236 & 0.287 \\
\hline $\mathrm{F}$ test $($ Prob $>F)$ & 0.00 & 0.00 & & \\
\hline Number of id & & & 3,777 & 1,536 \\
\hline
\end{tabular}

Sources: Authors' computations using ELMPS data, 1998, 2006, 2012.

Notes: 1$) * * *, * *$ and $*$ indicate significance at 1,5 and 10 percent levels respectively.

2) For OLS and FE robust standard errors are in parenthesis. 
TABLE A2: Mincer Earnings Equations, Quantile Regression, Male Sample, Egypt, 1998-2012

\begin{tabular}{|c|c|c|c|c|c|}
\hline VARIABLES & $\begin{array}{l}(1) \\
q 10\end{array}$ & $\begin{array}{l}(2) \\
\mathrm{q} 25\end{array}$ & $\begin{array}{l}(3) \\
q 50\end{array}$ & $\begin{array}{l}(4) \\
\text { q75 }\end{array}$ & $\begin{array}{c}(5) \\
q 90\end{array}$ \\
\hline Public wage gap & $\begin{array}{l}-0.0582 \\
(0.0455)\end{array}$ & $\begin{array}{c}-0.1057 * * * \\
(0.0273)\end{array}$ & $\begin{array}{c}-0.1362 * * * \\
(0.0303)\end{array}$ & $\begin{array}{c}-0.1934 * * * \\
(0.0329)\end{array}$ & $\begin{array}{c}-0.1932 * * * \\
(0.0536)\end{array}$ \\
\hline Age & $\begin{array}{l}0.0222 * * \\
(0.0112)\end{array}$ & $\begin{array}{c}0.0180 * * \\
(0.0071)\end{array}$ & $\begin{array}{c}0.0234 * * * \\
(0.0077)\end{array}$ & $\begin{array}{c}0.0117 \\
(0.0080)\end{array}$ & $\begin{array}{c}0.0375 * * \\
(0.0157)\end{array}$ \\
\hline Age Squared & $\begin{array}{c}-0.0000 \\
(0.0001)\end{array}$ & $\begin{array}{c}0.0000 \\
(0.0001)\end{array}$ & $\begin{array}{c}0.0000 \\
(0.0001)\end{array}$ & $\begin{array}{c}0.0001 \\
(0.0001)\end{array}$ & $\begin{array}{c}-0.0002 \\
(0.0002)\end{array}$ \\
\hline Year of Schooling & $\begin{array}{c}0.0638 * * * \\
(0.0033)\end{array}$ & $\begin{array}{c}0.0620 * * * \\
(0.0023)\end{array}$ & $\begin{array}{c}0.0596 * * * \\
(0.0022)\end{array}$ & $\begin{array}{c}0.0579 * * * \\
(0.0020)\end{array}$ & $\begin{array}{c}0.0591 * * * \\
(0.0040)\end{array}$ \\
\hline Married & $\begin{array}{c}0.1593 * * * \\
(0.0437)\end{array}$ & $\begin{array}{c}0.1585 * * * \\
(0.0258)\end{array}$ & $\begin{array}{c}0.1074 * * * \\
(0.0271)\end{array}$ & $\begin{array}{c}0.0716 * * \\
(0.0325)\end{array}$ & $\begin{array}{c}0.0093 \\
(0.0684)\end{array}$ \\
\hline Children & $\begin{array}{l}-0.0607 * \\
(0.0322)\end{array}$ & $\begin{array}{c}-0.0760 * * * \\
(0.0200)\end{array}$ & $\begin{array}{l}-0.0420 * \\
(0.0218)\end{array}$ & $\begin{array}{l}-0.0332 \\
(0.0259)\end{array}$ & $\begin{array}{l}-0.0495 \\
(0.0482)\end{array}$ \\
\hline Household size & $\begin{array}{c}0.0009 \\
(0.0067)\end{array}$ & $\begin{array}{c}0.0083 \\
(0.0058)\end{array}$ & $\begin{array}{l}0.0075^{* * *} \\
(0.0032)\end{array}$ & $\begin{array}{c}0.0017 \\
(0.0047)\end{array}$ & $\begin{array}{c}0.0065 \\
(0.0104)\end{array}$ \\
\hline \multicolumn{6}{|l|}{ Sector } \\
\hline Construction & $\begin{array}{l}0.1268 * \\
(0.0752)\end{array}$ & $\begin{array}{c}0.1434 * * \\
(0.0563)\end{array}$ & $\begin{array}{c}0.2182 * * * \\
(0.0773)\end{array}$ & $\begin{array}{c}0.2314 * * * \\
(0.0600)\end{array}$ & $\begin{array}{c}0.3295 * * \\
(0.1677)\end{array}$ \\
\hline Trade & $\begin{array}{c}-0.2498 * * * \\
(0.0729)\end{array}$ & $\begin{array}{c}-0.2280 * * * \\
(0.0547)\end{array}$ & $\begin{array}{c}-0.1794 * * * \\
(0.0473)\end{array}$ & $\begin{array}{c}-0.1479 * * * \\
(0.0494)\end{array}$ & $\begin{array}{l}-0.1344 \\
(0.0834)\end{array}$ \\
\hline Transportation & $\begin{array}{c}-0.0154 \\
(0.0452)\end{array}$ & $\begin{array}{c}0.1000 * * * \\
(0.0307)\end{array}$ & $\begin{array}{c}0.1098 * * * \\
(0.0309)\end{array}$ & $\begin{array}{c}0.1873 * * * \\
(0.0363)\end{array}$ & $\begin{array}{l}0.1605 * * \\
(0.0716)\end{array}$ \\
\hline $\begin{array}{l}\text { Finance \& } \\
\text { Services }\end{array}$ & $-0.1980 * * *$ & $-0.0820 * * *$ & $-0.0852 * * *$ & -0.0378 & -0.0659 \\
\hline & $(0.0457)$ & $(0.0291)$ & $(0.0256)$ & $(0.0318)$ & $(0.0606)$ \\
\hline \multicolumn{6}{|l|}{ Region } \\
\hline $\begin{array}{l}\text { Alexandria, } \mathrm{Sz} \\
\text { C. }\end{array}$ & -0.0073 & -0.0260 & -0.0471 & $(0.0389)$ & $\begin{array}{l}-0.0957 \\
(0.0654)\end{array}$ \\
\hline Urban Lower & $\begin{array}{l}-0.0602 \\
(0.0462)\end{array}$ & $\begin{array}{c}-0.1381 * * * \\
(0.0372)\end{array}$ & $\begin{array}{c}-0.1644 * * * \\
(0.0313)\end{array}$ & $\begin{array}{c}-0.1987 * * * \\
(0.0366)\end{array}$ & $\begin{array}{c}-0.2145 * * * \\
(0.0785)\end{array}$ \\
\hline Urban Upper & $\begin{array}{l}-0.0842 \\
(0.0554)\end{array}$ & $\begin{array}{c}-0.0737 * * \\
(0.0319)\end{array}$ & $\begin{array}{c}-0.1117 * * * \\
(0.0293)\end{array}$ & $\begin{array}{c}-0.1415 * * * \\
(0.0366)\end{array}$ & $\begin{array}{c}-0.2199 * * * \\
(0.0743)\end{array}$ \\
\hline Rural Lower & $\begin{array}{c}-0.1537 * * * \\
(0.0372)\end{array}$ & $\begin{array}{c}-0.2193 * * * \\
(0.0297)\end{array}$ & $\begin{array}{c}-0.2344 * * * \\
(0.0280)\end{array}$ & $\begin{array}{c}-0.2879 * * * \\
(0.0353)\end{array}$ & $\begin{array}{c}-0.3928 * * * \\
(0.0656)\end{array}$ \\
\hline Rural Upper & $\begin{array}{c}-0.1448 * * * \\
(0.0507)\end{array}$ & $\begin{array}{c}-0.1885 * * * \\
(0.0323)\end{array}$ & $\begin{array}{c}-0.1713 * * * \\
(0.0310)\end{array}$ & $\begin{array}{c}-0.1932 * * * \\
(0.0402)\end{array}$ & $\begin{array}{c}-0.1943 * * \\
(0.0895)\end{array}$ \\
\hline Year & & & & & \\
\hline 2006 & $\begin{array}{l}0.2029 * * * \\
(0.0271)\end{array}$ & $\begin{array}{l}0.2254 * * * \\
(0.0219)\end{array}$ & $\begin{array}{l}0.2270 * * * \\
(0.0174)\end{array}$ & $\begin{array}{l}0.1881 * * * \\
(0.0210)\end{array}$ & $\begin{array}{c}0.3260 * * * \\
(0.0561)\end{array}$ \\
\hline 2012 & $\begin{array}{c}0.1538 * * * \\
(0.0353)\end{array}$ & $\begin{array}{c}0.2443 * * * \\
(0.0235)\end{array}$ & $\begin{array}{c}0.3045 * * * \\
(0.0201)\end{array}$ & $\begin{array}{c}0.3351 * * * \\
(0.0224)\end{array}$ & $\begin{array}{c}0.3644 * * * \\
(0.0434)\end{array}$ \\
\hline Constant & $\begin{array}{c}-0.6753 * * * \\
(0.2125)\end{array}$ & $\begin{array}{c}-0.3626 * * \\
(0.1409)\end{array}$ & $\begin{array}{l}-0.1304 \\
(0.1468)\end{array}$ & $\begin{array}{c}0.5651 * * * \\
(0.1538)\end{array}$ & $\begin{array}{l}0.5491 * \\
(0.2891)\end{array}$ \\
\hline Observations & 6,131 & 6,131 & 6,131 & 6,131 & 6,131 \\
\hline
\end{tabular}

Sources: Authors' computations using ELMPS data, 1998, 2006, 2012.

Notes: 1) $* * * * *$ and $*$ indicate significance at 1,5 and 10 percent levels respectively.

2) Bootstrap standard errors are in parenthesis (100 replications). 
TABLE A3: Mincer Earnings Equations, Quantile Regression, Female Sample, Egypt, 1998-2012

\begin{tabular}{|c|c|c|c|c|c|}
\hline & (1) & (2) & (3) & (4) & (5) \\
\hline VARIABLES & $\mathrm{q} 10$ & q25 & q50 & q75 & q90 \\
\hline Public wage gap & $\begin{array}{l}0.1822 * \\
(0.1019)\end{array}$ & $\begin{array}{l}0.1539 * * * \\
(0.0518)\end{array}$ & $\begin{array}{l}0.1352 * * * \\
(0.0501)\end{array}$ & $\begin{array}{c}0.0727 \\
(0.0521)\end{array}$ & $\begin{array}{c}0.0496 \\
(0.0903)\end{array}$ \\
\hline Age & $\begin{array}{l}0.0400 * * * \\
(0.0130)\end{array}$ & $\begin{array}{l}0.0505 * * * \\
(0.0106)\end{array}$ & $\begin{array}{l}0.0410 * * * \\
(0.0104)\end{array}$ & $\begin{array}{c}0.0362 * * * \\
(0.0092)\end{array}$ & $\begin{array}{c}0.0212 \\
(0.0176)\end{array}$ \\
\hline Age Squared & $\begin{array}{l}-0.0000 \\
(0.0002)\end{array}$ & $\begin{array}{l}-0.0002 * \\
(0.0001)\end{array}$ & $\begin{array}{l}-0.0002 \\
(0.0001)\end{array}$ & $\begin{array}{l}-0.0001 \\
(0.0001)\end{array}$ & $\begin{array}{c}0.0000 \\
(0.0002)\end{array}$ \\
\hline Year of Schooling & $\begin{array}{c}0.0791 * * * \\
(0.0068)\end{array}$ & $\begin{array}{c}0.0776 * * * \\
(0.0064)\end{array}$ & $\begin{array}{l}0.0706^{* * * *} \\
(0.0051)\end{array}$ & $\begin{array}{l}0.0635^{* * * *} \\
(0.0048)\end{array}$ & $\begin{array}{c}0.0634 * * * \\
(0.0105)\end{array}$ \\
\hline Married & $\begin{array}{c}0.0864 \\
(0.0637)\end{array}$ & $\begin{array}{l}0.1096 * * * \\
(0.0338)\end{array}$ & $\begin{array}{c}0.0747 * * * \\
(0.0286)\end{array}$ & $\begin{array}{l}0.0920 * * * \\
(0.0323)\end{array}$ & $\begin{array}{c}0.0366 \\
(0.0525)\end{array}$ \\
\hline Children & $\begin{array}{c}0.0122 \\
(0.0499)\end{array}$ & $\begin{array}{l}-0.0217 \\
(0.0349)\end{array}$ & $\begin{array}{c}0.0096 \\
(0.0323)\end{array}$ & $\begin{array}{l}-0.0059 \\
(0.0401)\end{array}$ & $\begin{array}{l}-0.0649 \\
(0.0641)\end{array}$ \\
\hline Household size & 0.0093 & -0.0038 & 0.0019 & -0.0091 & -0.0071 \\
\hline Sector & $(0.0121)$ & $(0.0086)$ & $(0.0056)$ & $(0.0095)$ & $(0.0150)$ \\
\hline Construction & $\begin{array}{l}-0.7436 \\
(0.6173)\end{array}$ & $\begin{array}{c}0.1919 \\
(0.4294)\end{array}$ & $\begin{array}{c}0.3860 \\
(0.3111)\end{array}$ & $\begin{array}{c}0.3244 \\
(0.4715)\end{array}$ & $\begin{array}{c}0.6942 \\
(0.4379)\end{array}$ \\
\hline Trade & $\begin{array}{l}-0.2661 \\
(0.2059)\end{array}$ & $\begin{array}{l}-0.1563 \\
(0.2045)\end{array}$ & $\begin{array}{l}-0.0418 \\
(0.1023)\end{array}$ & $\begin{array}{l}-0.0820 \\
(0.1365)\end{array}$ & $\begin{array}{l}-0.3074 * \\
(0.1611)\end{array}$ \\
\hline Transportation & $\begin{array}{l}-0.4127 \\
(0.2901)\end{array}$ & $\begin{array}{l}-0.1290 \\
(0.1204)\end{array}$ & $\begin{array}{l}-0.1184 \\
(0.1124)\end{array}$ & $\begin{array}{l}-0.1692 \\
(0.1403)\end{array}$ & $\begin{array}{l}-0.2037 \\
(0.2703)\end{array}$ \\
\hline $\begin{array}{l}\text { Finance \& } \\
\text { Services }\end{array}$ & $-0.3445 * * *$ & $-0.2639 * * *$ & $-0.2216^{* * *}$ & $-0.2901 * * *$ & $-0.3078 * *$ \\
\hline & $(0.1005)$ & $(0.0791)$ & $(0.0643)$ & $(0.0560)$ & $(0.1240)$ \\
\hline Region & & & & & \\
\hline $\begin{array}{l}\text { Alexandria, } \mathrm{Sz} \\
\text { C. }\end{array}$ & -0.0879 & $-0.1386^{* *}$ & $-0.1300 * * *$ & $-0.1214 * *$ & $-0.2310 * * *$ \\
\hline & $(0.0590)$ & $(0.0540)$ & $(0.0415)$ & $(0.0549)$ & $(0.0840)$ \\
\hline Urban Lower & $\begin{array}{c}-0.1317 * * \\
(0.0611)\end{array}$ & $\begin{array}{c}-0.1562 * * * \\
(0.0385)\end{array}$ & $\begin{array}{c}-0.1829 * * * \\
(0.0377)\end{array}$ & $\begin{array}{c}-0.2379 * * * \\
(0.0450)\end{array}$ & $\begin{array}{c}-0.3487 * * * \\
(0.0783)\end{array}$ \\
\hline Urban Upper & $\begin{array}{c}-0.1218 * * \\
(0.0561)\end{array}$ & $\begin{array}{c}-0.1482 * * * \\
(0.0400)\end{array}$ & $\begin{array}{c}-0.1381 * * * \\
(0.0333)\end{array}$ & $\begin{array}{c}-0.1414 * * * \\
(0.0497)\end{array}$ & $\begin{array}{c}-0.2341 * * * \\
(0.0779)\end{array}$ \\
\hline Rural Lower & $\begin{array}{l}-0.1176^{*} \\
(0.0632)\end{array}$ & $\begin{array}{c}-0.1431 * * * \\
(0.0439)\end{array}$ & $\begin{array}{c}-0.2011 * * * \\
(0.0336)\end{array}$ & $\begin{array}{c}-0.2446 * * * \\
(0.0458)\end{array}$ & $\begin{array}{c}-0.2958 * * * \\
(0.0789)\end{array}$ \\
\hline Rural Upper & $\begin{array}{c}-0.3313 * * * \\
(0.1200)\end{array}$ & $\begin{array}{c}-0.2506 * * * \\
(0.0659)\end{array}$ & $\begin{array}{c}-0.1744 * * * \\
(0.0498)\end{array}$ & $\begin{array}{c}-0.2133 * * * \\
(0.0778)\end{array}$ & $\begin{array}{l}-0.1309 \\
(0.1695)\end{array}$ \\
\hline Year & & & & & \\
\hline 2006 & $\begin{array}{c}0.1967 * * * \\
(0.0438)\end{array}$ & $\begin{array}{c}0.2195 * * * \\
(0.0342)\end{array}$ & $\begin{array}{c}0.1434 * * * \\
(0.0293)\end{array}$ & $\begin{array}{c}0.1596^{* * * *} \\
(0.0343)\end{array}$ & $\begin{array}{c}0.2404 * * * \\
(0.0518)\end{array}$ \\
\hline 2012 & $\begin{array}{c}0.0396 \\
(0.0475)\end{array}$ & $\begin{array}{c}0.2115^{* * * *} \\
(0.0396)\end{array}$ & $\begin{array}{c}0.2964 * * * \\
(0.0340)\end{array}$ & $\begin{array}{c}0.3218 * * * \\
(0.0403)\end{array}$ & $\begin{array}{c}0.3357 * * * \\
(0.0461)\end{array}$ \\
\hline Constant & $\begin{array}{c}-1.5865^{* * * *} \\
(0.2947)\end{array}$ & $\begin{array}{c}-1.3842 * * * \\
(0.2154)\end{array}$ & $\begin{array}{c}-0.7781^{* * *} * \\
(0.1968)\end{array}$ & $\begin{array}{c}-0.1238 \\
(0.1796)\end{array}$ & $\begin{array}{c}0.6717 * * \\
(0.3400)\end{array}$ \\
\hline Observations & 2,697 & 2,697 & 2,697 & 2,697 & 2,697 \\
\hline
\end{tabular}

Sources: Authors' computations using ELMPS data, 1998, 2006, 2012.

Notes: 1$) * * *, * *$ and * indicate significance at 1,5 and 10 percent levels respectively.

2) Bootstrap standard errors are in parenthesis, 100 replications. 
TABLE A4: Mincer Earnings Equations, Fixed Effect Quantile Regression, Male Sample, Egypt, 19982012

\begin{tabular}{|c|c|c|c|c|c|}
\hline VARIABLES & $\begin{array}{l}(1) \\
q 10\end{array}$ & $\begin{array}{l}(2) \\
\mathrm{q} 25\end{array}$ & $\begin{array}{l}(3) \\
\text { q50 }\end{array}$ & $\begin{array}{l}(4) \\
q 75\end{array}$ & $\begin{array}{l}(5) \\
\text { q90 }\end{array}$ \\
\hline Public wage gap & $\begin{array}{c}-0.2639 * * * \\
(0.0349)\end{array}$ & $\begin{array}{c}-0.2976 * * * \\
(0.0157)\end{array}$ & $\begin{array}{c}-0.2779 * * * \\
(0.0000)\end{array}$ & $\begin{array}{c}-0.2192 * * * \\
(0.0192)\end{array}$ & $\begin{array}{c}-0.2707 * * * \\
(0.0296)\end{array}$ \\
\hline Age & $\begin{array}{c}0.0108 \\
(0.0079)\end{array}$ & $\begin{array}{c}0.0351 * * * \\
(0.0034)\end{array}$ & $\begin{array}{c}0.0498 * * * \\
(0.0000)\end{array}$ & $\begin{array}{c}0.0570 * * * \\
(0.0026)\end{array}$ & $\begin{array}{c}0.0796 * * * \\
(0.0084)\end{array}$ \\
\hline Age Squared & $\begin{array}{c}0.0000 \\
(0.0001)\end{array}$ & $\begin{array}{c}-0.0003 * * * \\
(0.0000)\end{array}$ & $\begin{array}{c}-0.0004 * * * \\
(0.0000)\end{array}$ & $\begin{array}{c}-0.0005 * * * \\
(0.0000)\end{array}$ & $\begin{array}{c}-0.0007 * * * \\
(0.0001)\end{array}$ \\
\hline Year of Schooling & $\begin{array}{c}0.0022 \\
(0.0025)\end{array}$ & $\begin{array}{c}0.0009 \\
(0.0008)\end{array}$ & $\begin{array}{c}0.0026 * * * \\
(0.0000)\end{array}$ & $\begin{array}{c}0.0041 * * * \\
(0.0009)\end{array}$ & $\begin{array}{c}0.0061 * * \\
(0.0028)\end{array}$ \\
\hline Married & $\begin{array}{c}0.1452 * * * \\
(0.0311)\end{array}$ & $\begin{array}{c}0.1387 * * * \\
(0.0092)\end{array}$ & $\begin{array}{c}0.1214 * * * \\
(0.0000)\end{array}$ & $\begin{array}{c}0.1222 * * * \\
(0.0073)\end{array}$ & $\begin{array}{c}0.1000 * * * \\
(0.0388)\end{array}$ \\
\hline Children & $\begin{array}{c}-0.0694 * * \\
(0.0283)\end{array}$ & $\begin{array}{c}-0.0505 * * * \\
(0.0112)\end{array}$ & $\begin{array}{c}-0.0142 * * * \\
(0.0000)\end{array}$ & $\begin{array}{l}0.0210^{*} \\
(0.0115)\end{array}$ & $\begin{array}{c}0.0223 \\
(0.0285)\end{array}$ \\
\hline Household size & $\begin{array}{c}0.0136 * * \\
(0.0055)\end{array}$ & $\begin{array}{c}0.0150 * * * \\
(0.0023)\end{array}$ & $\begin{array}{c}0.0129 * * * \\
(0.0000)\end{array}$ & $\begin{array}{c}0.0126 * * * \\
(0.0024)\end{array}$ & $\begin{array}{c}0.0119 * * \\
(0.0052)\end{array}$ \\
\hline \multicolumn{6}{|l|}{ Sector } \\
\hline Construction & $\begin{array}{l}-0.0024 \\
(0.0413)\end{array}$ & $\begin{array}{c}-0.0836 * * * \\
(0.0101)\end{array}$ & $\begin{array}{c}-0.0966 * * * \\
(0.0000)\end{array}$ & $\begin{array}{c}-0.1028 * * * \\
(0.0096)\end{array}$ & $\begin{array}{c}-0.1941 * * * \\
(0.0540)\end{array}$ \\
\hline Trade & $\begin{array}{c}0.0516 \\
(0.0668)\end{array}$ & $\begin{array}{c}0.0025 \\
(0.0093)\end{array}$ & $\begin{array}{c}-0.0042 * * * \\
(0.0000)\end{array}$ & $\begin{array}{c}-0.0041 \\
(0.0077)\end{array}$ & $\begin{array}{c}-0.0385 \\
(0.0444)\end{array}$ \\
\hline Transportation & $\begin{array}{c}0.0156 \\
(0.0403)\end{array}$ & $\begin{array}{c}0.0270 * * * \\
(0.0091)\end{array}$ & $\begin{array}{c}0.0348 * * * \\
(0.0000)\end{array}$ & $\begin{array}{c}0.0397 * * * \\
(0.0088)\end{array}$ & $\begin{array}{c}0.0560 \\
(0.0431)\end{array}$ \\
\hline $\begin{array}{l}\text { Finance \& } \\
\text { Services }\end{array}$ & $-0.1680 * * *$ & $-0.1504 * * *$ & $-0.1037 * * *$ & $-0.0721 * * *$ & -0.0504 \\
\hline & $(0.0369)$ & $(0.0182)$ & $(0.0000)$ & $(0.0184)$ & $(0.0378)$ \\
\hline \multicolumn{6}{|l|}{ Region } \\
\hline $\begin{array}{l}\text { Alexandria, } \mathrm{Sz} \\
\text { C. }\end{array}$ & $0.5772 * * *$ & $0.5177 * * *$ & $0.5232 * * *$ & $0.5447 * * *$ & $0.4979 * * *$ \\
\hline & $(0.0449)$ & $(0.0140)$ & $(0.0000)$ & $(0.0169)$ & $(0.0425)$ \\
\hline Urban Lower & $\begin{array}{c}0.6802 * * * \\
(0.0396)\end{array}$ & $\begin{array}{c}0.5880 * * * \\
(0.0126)\end{array}$ & $\begin{array}{c}0.5825 * * * \\
(0.0000)\end{array}$ & $\begin{array}{c}0.5799 * * * \\
(0.0105)\end{array}$ & $\begin{array}{c}0.4913 * * * \\
(0.0400)\end{array}$ \\
\hline Urban Upper & $\begin{array}{c}0.1036 * * * \\
(0.0395)\end{array}$ & $\begin{array}{c}0.0470 * * * \\
(0.0160)\end{array}$ & $\begin{array}{c}0.0370 * * * \\
(0.0000)\end{array}$ & $\begin{array}{l}0.0207 * \\
(0.0108)\end{array}$ & $\begin{array}{c}0.0120 \\
(0.0431)\end{array}$ \\
\hline Rural Lower & $\begin{array}{c}0.7921 * * * \\
(0.0354)\end{array}$ & $\begin{array}{c}0.6763 * * * \\
(0.0112)\end{array}$ & $\begin{array}{c}0.6754 * * * \\
(0.0000)\end{array}$ & $\begin{array}{c}0.6801 * * * \\
(0.0090)\end{array}$ & $\begin{array}{c}0.5797 * * * \\
(0.0378)\end{array}$ \\
\hline Rural Upper & $\begin{array}{c}0.0096 \\
(0.0451)\end{array}$ & $\begin{array}{c}-0.0465 * * * \\
(0.0140)\end{array}$ & $\begin{array}{c}-0.0616 * * * \\
(0.0000)\end{array}$ & $\begin{array}{c}-0.0702 * * * \\
(0.0110)\end{array}$ & $\begin{array}{c}-0.1167 * * \\
(0.0467)\end{array}$ \\
\hline Year & & & & & \\
\hline 2006 & $\begin{array}{c}0.3621 * * * \\
(0.0269)\end{array}$ & $\begin{array}{c}0.3529 * * * \\
(0.0125)\end{array}$ & $\begin{array}{c}0.3889 * * * \\
(0.0000)\end{array}$ & $\begin{array}{c}0.3618 * * * \\
(0.0174)\end{array}$ & $\begin{array}{c}0.3571 * * * \\
(0.0297)\end{array}$ \\
\hline 2012 & $\begin{array}{c}0.5190 * * * \\
(0.0323)\end{array}$ & $\begin{array}{c}0.5227 * * * \\
(0.0128)\end{array}$ & $\begin{array}{c}0.5096 * * * \\
(0.0000)\end{array}$ & $\begin{array}{c}0.4847 * * * \\
(0.0166)\end{array}$ & $\begin{array}{c}0.4469 * * * \\
(0.0338)\end{array}$ \\
\hline Constant & $\begin{array}{c}0.1946 \\
(0.1450)\end{array}$ & $\begin{array}{l}-0.0112 \\
(0.0562)\end{array}$ & $\begin{array}{c}-0.2704 * * * \\
(0.0000)\end{array}$ & $\begin{array}{c}-0.3927 * * * \\
(0.0542)\end{array}$ & $\begin{array}{c}-0.5593 * * * \\
(0.1656)\end{array}$ \\
\hline Observations & 6,131 & 6,131 & 6,131 & 6,131 & 6,131 \\
\hline
\end{tabular}

Sources: Authors' computations using ELMPS data, 1998, 2006, 2012.

Notes: 1$) * * *, * *$ and $*$ indicate significance at 1,5 and 10 percent levels respectively.

2) Bootstrap standard errors are in parenthesis, 100 replications. 


\section{APPENDIX-B}

\section{Sample Selection Correction in Quantile Regression Model}

In this appendix we present the sample selection correction method in a quantile regression model. In the presentation below we use the same notation as Buchinski $(1998 ; 2001)$ and Pianto and Pianto (2002) and summarize the discussion in these references. This method is a variant of the standard Heckman two-step procedure used to control for sample selectivity. It is similar to that previously suggested by Heckman (1979) and extended by Newey (1999) for the mean regression. It is introduced by Buchinsky (1998) and based on a nonparametric correction method. As usual there are two stages. In the first step, we use a simple probit model to estimate the probabilities of workers being in the public or private sector. However, we don't want to impose the restriction of normality. Therefore, a semi-parametric method which is developed by Ichimura (1993) is used. This makes no assumptions about the distribution of the residuals. We now summarize the steps involved.

First, a binary variable $d_{i}$ and a latent or index variable $g$ for public versus private sector selection are defined as follows:

$d_{i}=\left\{\begin{array}{l}1: g_{i}>0, \text { public sector } \\ 0: g_{i}<0, \text { private sector }\end{array}\right.$

The likelihood of a person $i$ working in the public sector is given by the following equation where $x_{i}$ is a set of personal characteristics:

$g_{i}=x_{1 i}^{\prime} \gamma+v_{i}$

In the second step, we write a public wage offer equation as a quantile regression as follows:

$y_{i}^{o}=x_{2 i}^{\prime} \beta_{\theta}+u_{\theta i}$

where $x_{2}$ is a subset of $x_{1}$ and $u_{\theta i} \equiv x_{2 i}^{\prime}\left(\beta_{0}-\beta_{\theta}\right)+u_{i}$.

To obtain an unbiased estimate of beta in the wage equation, an extra term must be introduced to the model.

$y \equiv x_{2}^{\prime} \beta_{\theta}+h_{\theta}(\mathrm{g})+\varepsilon_{\theta}$

where $h_{\theta}(g) \equiv$ Quant $_{\theta}\left(u_{\theta} \mid x_{1}, g>0\right)$. This term includes information about the unobservable characteristics of public workers which affect their sector choice. 


\section{First Step Estimation:}

We obtain an estimate for the coefficient $\gamma$ in the equation (A1), by using the semi-parametric least squared (SLS) method. The estimator suggested by Ichimura (1993) is as follows:

$$
\hat{\gamma}=\arg \min _{\gamma \in \mathfrak{R}^{p}} \frac{1}{n} \sum_{i=1}^{n}\left(d_{i}-\hat{E}\left(d_{i} \mid x_{1 i} \gamma\right)\right)^{2}
$$

Where $\hat{E}\left(d_{i} \mid x_{1 i}, \gamma\right)$ is a kernel density estimate of $d_{i}$ with kernel function $\kappa($.) and its bandwidth $h$ and given by

$$
\hat{E}\left(d_{i} \mid x_{1 i}, \gamma\right)=\frac{\sum_{j \neq i} d_{j} \kappa\left(\left(x_{1 i}^{\prime} \gamma-x_{1 j}^{\prime} \gamma\right) / h\right)}{\sum_{j \neq i} \kappa\left(\left(x_{1 i}^{\prime} \gamma-x_{1 j}^{\prime} \gamma\right) / h\right)}
$$

The estimation of $\hat{\gamma}$ is obtained here is the same as in Buchinsky (1998). This estimator asymptotically normal and asymptotic covariance matrix is given by $\Lambda_{\gamma}=\Omega^{-1} \Sigma \Omega^{-1}$ for $\hat{\gamma}$. The estimation of $\Omega$ and $\Sigma$ are calculated using the following equations:

$$
\begin{aligned}
& \hat{\Omega}=\frac{1}{n} \sum_{i=1}^{n} \hat{f}^{2}\left(\hat{g}_{i}\right)\left(x_{1 i}-\hat{E}\left(x_{1 i} \mid x_{1 i}^{\prime} \hat{\gamma}\right)\left(x_{1 i}-\hat{E}\left(x_{1 i} \mid x_{1 i}^{\prime} \hat{\gamma}\right)^{\prime},\right.\right. \\
& \hat{\Sigma}=\frac{1}{n} \sum_{i=1}^{n} \hat{f}^{2}\left(\hat{g}_{i}\right)\left(d_{i}-\hat{E}\left(d_{i} \mid x_{1 i}, \gamma\right)\right)^{2}\left(x_{1 i}-\hat{E}\left(x_{1 i} \mid x_{1 i}^{\prime} \hat{\gamma}\right)\left(x_{1 i}-\hat{E}\left(x_{1 i} \mid x_{1 i}^{\prime} \hat{\gamma}\right)^{\prime} .\right.\right.
\end{aligned}
$$

where $\hat{f}(g)=d \hat{F}(g) / d g$ and $\hat{F}(g)=\hat{E}\left(d \mid x_{1}, \gamma\right)=\hat{E}(d \mid g)$

\section{Second Step Estimation:}

In the second step, we set up the quantile regression of $y$ on $x_{2}$ and $P_{s}(\hat{g})$ to obtain a consistent estimator for $\beta_{\theta}$, that is,

$$
y_{i}=x_{2 i}^{\prime} \hat{\beta}_{\theta}+P s\left(\hat{g}_{i}\right)^{\prime} \hat{\delta}_{\theta}+\hat{\varepsilon}_{\theta i} \quad\left\{i: d_{i}=1\right\}
$$

or

$$
y_{i}=x_{2 i}^{\prime} \hat{\beta}_{\theta}+\sum_{j=1}^{S}\left(\lambda\left(\hat{\mu}+\hat{\sigma} \hat{g}_{i}\right)\right)^{j-1} \hat{\delta}_{\theta j}+\hat{\varepsilon}_{\theta i}
$$

where the term $\hat{h}_{\theta}(g)=\hat{\delta}_{\theta}^{\prime} P s(\hat{g})$ controls for the sample selection and $P s(\hat{g})$ is a polynomial of order $\mathrm{S}$ in $\hat{g}$. Without additional assumption we cannot always define $P_{S 1}\left(\hat{g}_{i}\right) \equiv 1$ but we 
need to define $P_{S 1}\left(\hat{g}_{i}\right) \equiv 1$ to consistently estimates of the term in $\beta_{\theta}$ corresponding to the constant (Buchinsky, 2001).

The power series $P_{S j}(g)=(\hat{f}(g) / \hat{F}(g))^{j-1}$ is used in this study for the estimation of the quantile regression in the second step, where $\phi($.$) and \Phi($.$) are the density and cumulative$ distribution function of a standard normal variable, respectively. $\lambda()=.\phi(.) / \Phi($. $)$ is inverse Mill's ratio. $\hat{f}($.$) and \hat{F}($.$) are the nonparametric estimates of the density and cumulative$ distribution function of $\varepsilon_{i}$ respectively. The scaling parameters $\hat{\mu}$ and $\hat{\sigma}$ are needed for the normalization of $g_{i}$ by $\hat{\mu}+\hat{\sigma} g_{i}$. We choose the scaling parameters as the constant and slope coefficients from a probit regression of $d_{i}$ on the index $\hat{g}\left(x_{1 i}, \hat{\gamma}\right)$. 